Volume 6

Issue 1 Fall 2002

November 2015

\title{
Critical Legal and Policy Issues for People with Disabilities
}

Robert F. Rich

Christopher T. Erb

Rebecca A. Rich

Follow this and additional works at: https://via.library.depaul.edu/jhcl

\section{Recommended Citation}

Robert F. Rich, Christopher T. Erb \& Rebecca A. Rich, Critical Legal and Policy Issues for People with Disabilities, 6 DePaul J. Health Care L. 1 (2002)

Available at: https://via.library.depaul.edu/jhcl/vol6/iss1/2

This Article is brought to you for free and open access by the College of Law at Digital Commons@DePaul. It has been accepted for inclusion in DePaul Journal of Health Care Law by an authorized editor of Digital Commons@DePaul. For more information, please contact digitalservices@depaul.edu. 


\title{
CRITICAL LEGAL AND POLICY ISSUES FOR PEOPLE WITH DISABILITIES ${ }^{*}$
}

\author{
Robert F. Rich ${ }^{* *}$ \\ Christopher T. Erb ${ }^{* * *}$ \\ Rebecca A. Rich
}

A fifth of all Americans have some sort of disability and one in ten have a severe disability. Almost every American will face a disability at some point in their lifetime. ${ }^{\prime}$ The equivalent of $8 \%$ of the federal budget (approximately $\$ 175$ billion) is spent on government programs and services for people with disabilities annually, yet their problems and needs have only begun to be addressed. ${ }^{2}$ Since the passage of the

* The research reported herein was performed pursuant to a grant from the U.S. Social Security Administration (SSA) funded as part of the Disability Research Institute. The opinions and conclusions expressed are solely those of the author(s) and should not be construed as representing the opinions or policy of the SSA or any agency of the Federal Government.

** Robert F. Rich is a Professor of Law and Political Science at University of Illinois at Urbana-Champaign. He also has joint-appointments in the Institute of Government and Public Affairs and the College of Medicine at the University of Illinois at Urbana-Champaign. He holds a B.A. degree from Oberlin College and M.A. and Ph.D. degrees from University of Chicago.

${ }^{* *}$ Christopher T. Erb is an M.D./Ph.D. candidate in the Medical Scholars Program and the Department of Community Health at the University of Illinois at Urbana-Champaign. He holds a B.A. degree from The Colorado College.

**** Rebecca A. Rich is a law student at Boston College Law School. She holds a B.A. degree from Oberlin College.

${ }^{1}$ Census Brief, U.S.. Dep't of Commerce, Econ. and Stat. Admin., CENBR/97-5 (issued Dec. 1997), available at http://www.census.gov/prod/3/97pubs/cenbr975.pdf (last visited Jan. 3, 2003).

${ }^{2}$ This figure is estimated based on program and service expenditures for people with disabilities in the following programs: TANF, SSI, SSDI, food stamp programs, Medicaid, and Medicare. Note that this figure is an underestimate of the actual total of public expenditures for programs and services for people with disabilities. Not included in this estimate are payments from other federal programs, including Veterans Adninistration pension and compensation; Railroad Retirement; Black Lung Benefits; and Federal Employee Disability-Retirement. For a more detailed accounting of the expenditures used in this estimate, see John M. McNeil, Employment, Earnings, and Disability: 1992-93, 1993-94, 1994-95, and 1997, U.S. Bureau of 
Americans with Disabilities Act (ADA) of 1990, increasing attention has been given to this group in terms of legal and public policy development. Among the most critical current issues in disability policy are: employment status and incentives for people with disabilities; education availability and appropriateness; housing availability and access; insurance for health care and related services; and access to technology and other assistive devices. In addition, over the past two years, the legal definition of "disability" for the purpose of eligibility for government programs and services has been hotly debated in the public policy arena. Indeed, there have been eight Supreme Court cases since 1998 that deal with this controversial area. It is these issues and their attendant body of legislation and legal decisions that we seek to examine in this article.

The article is organized into five sections. First, we provide background on the prevalence of disability in America, describing this large minority group and outlining the major current disability-related policy issues. The next section details the foundation of disability policy in the United States, including the major programs and services that are available to people with disabilities and the major laws and statutes that are designed to offer protections for them in the major areas of employment, education, housing, health care, and technology accessibility.

Third, we analyze recent Court decisions related to major disability issues, focusing on Supreme Court decisions that have been precedent-setting in these areas. Fourth, we describe some of the continuing issues for people with disabilities in terms of what progress has been made and what remains to be done. In the fifth and final part of this article, we draw conclusions about where we stand as a society in our endeavor to end discrimination on the basis of disability. We also discuss some important implications that our current direction suggests for the future of disability policy in the United States.

\footnotetext{
the Census, (June 29 - July 3, 2000), available at http://www.census.gov/hhes/ www/disable/emperndis.pdf; Table 3: Distribution of Earnings and Benefits Received by Individuals 21 to 64 years old by Disability Status, U.S. Bureau of the Census, available at http://www.census.gov/hhes/www/ disable/emperndistbl.pdf. Estimates are derived from wave 5 of the 1996 Survey of Income and Program Participation.
} 


\section{WHO ARE PEOPLE WITH DISABILITIES?}

\section{Definitions}

The Americans with Disabilities Act of 1990 set the current standard definition for what is considered a disability under United States law. Under the ADA, a person with a disability is one who: "1) has a physical or mental impairment that substantially limits one or more major life activities, 2) has a record of such impairment, or 3) is thought to have such impairment." 3 It includes people with disabilities who need accommodations as well as those who do not, and is also inclusive of those who are thought to have disabilities as well as those who had disabilities in the past but no longer do. The ADA is not specific about which particular physical or mental impairments might qualify one for protection under its provisions. It instead leaves it up to the Equal Employment Opportunities Commission (EEOC) and other implementing agencies, such as the Departments of Education, Labor and Transportation, to make the determination of disability in individual circumstances.

The way disability is defined is critical because the definition is used to set eligibility criteria for public programs and to provide protection under the law. Slight variations in the definition of disability can mean a difference of millions of potentially eligible people with disabilities using billions of dollars in programs and services. Participation in the Social Security Disability Insurance Program (SSDI), for example, has increased by $160 \%$ since the mid 1980s from 4.4 million to 7.1 million enrollees, due in part to changes in the definition of disability used to define eligibility. ${ }^{4}$ For this reason, a variety of different definitions of disability have arisen in the context of specific disability programs. For example, because the Social Security Administration (SSA) operates a cash benefit program for people whose disability prevents them from working, it requires that potential beneficiaries have a "severe" disability":

${ }^{3}$ The Americans with Disabilities Act 42 U.S.C. $\$ 12101$ (2002).

${ }^{4}$ Mitch LaPlante, Jae Kennedy, and Laura Trupin, Disability Statistics Report, Income and Program Participation of People with Work Disabilities, U.S. Department of Education, Nat'I Institute on Disability and Rehabilitation Research, at 9 (Wash. D.C. 1997). The increase in SSDI enrollment has also been due to an absolute increase in the number of people with disabilities in the United States. See also http://www.census.gov/hhes/www/disability.html (last visited 12/12/02).

${ }^{5} 20$ C.F.R. $\S 404.1520$ (c) (2002). Evaluation of disability in general. 
"The law defines disability as the inability to do any substantial gainful activity by reason of any medically determinable physical or mental impairment which can be expected to result in death or which has lasted or can be expected to last for a continuous period of not less than 12 months. To meet this definition, you must have a severe impairment, which makes you unable to do your previous work or any other substantial gainful activity which exists in the national economy. To determine whether you are able to do any other work, we consider your residual functional capacity and your age, education, and work experience."

A severe disability is defined more specifically by the Census Bureau as a person who:

". . needed personal assistance with an $\mathrm{ADL}^{7}$ [Activity of Daily Living] or IADL [Instrumental Activity of Daily Living]; used a wheelchair; was a long term user of a cane, crutches, or a walker; had a developmental disability or Alzheimer's disease; was unable to do housework; was receiving federal disability benefits; or was 16 to 67 years old and unable to work at a job or business." 8

In addition to requiring that a potential beneficiary meet the severe disability criteria, the SSA stipulates that the individual must be unable to "do any substantial gainful activity by reason of any medically determinable physical or mental impairment which can be expected to

${ }^{6} 20$ C.F.R. $\$ 416.905$ (2002). Basic definition of disability for adults.

${ }^{7}$ The Activities of Daily Living (ADL) scale was developed by Sidney Katz and colleagues in 1963 and measures a person's ability to perform activities such as eating and bathing without accommodation, whereas the Instrumental Activities of Daily Living (IADL), developed in 1969 by Lawton and Brody, scale measures ability to perform more complex tasks such as cooking and money management without accommodation. These scales are also useful in work-related ADA accommodations because they can be used to help determine an employee's need and eligibility for job modifications. In fact, some of the most recent Supreme Court decisions described later in this article have hinged on the determination of whether a worker had a limitation in a major life activity that qualified her for accommodation under the ADA (see infra note 111, Toyota, 2002).

${ }^{8}$ Derinition of disability items in Census 2000 , available at http://www.census.gov/ hhes/www/disable/disdef00.html (last visited Dec. 12, 2002)." 
result in death or which has lasted or can be expected to last for a continuous period of not less than 12 months." This definition is clearly limited to a person's ability to function in the workplace, and does not necessarily take into account a person's abilities or limitations in other areas of life. This is in contrast to the World Health Organization's definition of disability as "an umbrella term for impairments, activity limitations or participation limitations." ${ }^{10}$ This is a more inclusive definition that allows for consideration of impairment of other important life activities, such as walking, bathing or eating, that may seriously limit a person's ability to perform basic tasks, whether or not he is capable of working.

Children are considered a special category of people with disabilities, and the Social Security Administration's definition for program eligibility considers a children to have a disability when they have:

\begin{abstract}
"a medically determinable physical or mental impairment or combination of impairments that causes marked and severe functional limitations, and that can be expected to cause death or that has lasted or can be expected to last for a continuous period of not less than 12 months." 11
\end{abstract}

However, like the ADA, this definition does not specifically list those disabilities that may be considered significant enough to create eligibility for programs. To clarify, the creators of the Individuals with Disabilities Education Act (IDEA) provided a list of examples of disabilities that may qualify children for protection. Under its rules:
"The term 'child with a disability' means a child -- (i) with mental retardation, hearing impairments (including deafness), speech or language impairments, visual impairments (including blindness), serious emotional disturbance..., orthopedic impairments, autism, traumatic

20 C.F.R. $\$ 416.905$ (2002); for further explanation of eligibility requirements for Social Security benefits, see The Social Security Administration. Social Security Disability Planner. Available at: http://www.ssa.gov/dibplan/dqualify4.htm (last visited Jan. 3, 2003).

10 World Health Organization, International Classification of Functioning and Disability, and Health (1999), available at http://www. who.int/classifications/icf/intros/ICFEng-Intro.pdf (last visited Dec. 12, 2002).

${ }^{11} 20$ C.F.R. 4 16.906. Basic definition of disability for children. See also Social Security Administration, Publication No. 05-11053 (July 1997), available at http:/www.ssa.gov/ pubs/1 1053.html (last visited Dec. 12, 2002), for further discussion of disability in children. 
brain injury, other health impairments, or specific learning disabilities; and (ii) who, by reason thereof, needs special education and related services." ${ }^{12}$

\section{Trends}

The number of people with disabilities in the United States has steadily but slowly increased since 1990, and it will continue to do so. The total number of people with disabilities increased by $5 \%$ in the first five years after the passage of the $\mathrm{ADA}$ and has continued to increase slightly each year since then. However, the number of people whose disabilities prevent them from working has decreased slightly during this time period. For example, estimates from the 1990 census showed that 48.9 million Americans (19.4\%) aged 21 to 64 had a disability. Of these, about half ( 24 million) had a severe disability. By 1997 the total number of people with disabilities was 53 million and those with severe disabilities numbered 26.5 million. This trend has both positive and negative implications for disability policymakers. First, that the numbers are only modestly increasing suggests that progress has been made in the prevention and treatment of medical and physical impairment over the last decade. It also suggests that some significant strides have been made in helping people with disabilities return to and remain in the workforce.

Nonetheless, a significant number of Americans remain functionally disabled, with limited ability to earn a living and participate in society. As a result of the limitations that people's disabilities place on them, they may find it difficult to gain access to a variety of services and activities that would otherwise be available to them. The problem of access is only partly related to an individual's impairment, and is often a result of discrimination or ignorance on the part of others.

\section{People with disabilities' access to and participation in society}

People with disabilities experience barriers to participation in society in a variety of critical areas. In our health care system, in which insurance is intimately tied to employment, people with disabilities often lack adequate insurance coverage to pay for their medical bills. Not only are their health care expenses greater, but their incomes are lower and

12 See H.R. 5, $\$ 602,(3)(A)$. The Individuals with Disabilities Education Act was amended in 1999 to include Attention Deficit Disorder (ADD) and Attention Deficit Hyperactivity Disorder (ADHD) on a case by case basis. 
they are almost twice as likely to be below the federal poverty level (FPL) than the general population $(28.6 \%$ of people with disabilities live below the poverty level versus $15.6 \%$ of the general U.S. population). ${ }^{13}$ This creates a significant financial burden for people with disabilities, their families, and the government programs that help support them. Because they are poor, people with disabilities also have limited access to housing and to technological advances such as computers and the Internet. For example, while a little over $67 \%$ of Americans without disabilities are homeowners, less than $10 \%$ of people with disabilities own homes. ${ }^{14}$ In this part of the article, we highlight the problems of employment, education, housing, health care and technology for people with disabilities. We first outline these major issues, providing some statistics and background information, and then describe the current services that are available to people with disabilities and the laws that help ensure that those services are accessible.

\section{Employment and Economics}

Unemployment rates for people with disabilities are more than double those for the general population, ${ }^{15}$ and those who acquire disabilities on the job are often unlikely to return to work because of the financial and health benefit disincentives associated with leaving guaranteed public programs for uncertain, employer-sponsored plans. $^{16}$ The unemployment rate for people with severe disabilities has remained relatively constant at about $70 \%$ compared to non-disabled adults, ${ }^{17}$ whose unemployment rate is just over $5 \%$. People with non-severe

${ }^{13}$ Texas Council for Developmental Disabilities, Texas Year 2000 Biennial Report: Imagine the Possibilities, Imagine the Hope, Section 2 (2000), available at http://www.txddc.state.tx.us/publications/biennial_report/brsec2.pdf (last visited Jan. 3, 2003)

14 Jack McNeil, U.S. Census Bureau, Current Population Reports, Americans with Disabilities: Household Economic Studies, 1997, pp. $70-73$ (2001). Jack McNeil, U.S. Census Bureau, Current Population Reports, Americans with Disabilities: Household Economic Studies, 1997, pp. 70-73 (2001).

${ }^{15}$ See Craig Zwerling et al., Workforce Participation by Persons with Disabilities: The Nat'l Health Interview Survey Disability Supplement, 1994 to 1995, 44 J. OF OccupationaL AND ENVTL. MED., 358-364 (2002).

${ }^{16}$ Steven J. Atlas et al., Long-term disability and Return to work among patients who have a herniated lumbar disc: The effect of Disability Compensation, 82-A(1) J. OF BONE AND JOINT SURGERY 4-15 (2000).

${ }^{17}$ Mitch LaPlante et al., Disability Statistics Report, U.S. DEPARTMENT OF EdUCATION, NAT'L INSTITUTE ON Disability and Rehabilitation RESEARCh 11 (1996); see also, supra note 14 . 
disabilities have an unemployment rate of $18 \%{ }^{18}$ As could be expected given these high unemployment rates, the poverty rates for people with disabilities are much higher than for non-disabled people $(27.9 \%$ compared to $8.3 \%) .{ }^{19}$

Among people with severe disabilities who could work, it has been well documented that real and perceived financial barriers exist that prevent thern from doing so. A 1998 Harris Survey estimated that $72 \%{ }^{20}$ of those people with disabilities who do not work would like to, but have not sought employment for fear of losing their health insurance and disability income from SSDI. ${ }^{21}$ It is this group of people with disabilities caught in the middle -- those who could work with minimal but important accommodations -- that are affected most by these gaps in coverage. ${ }^{22}$ As one commentator for a disability rights organization put it: "Either you live without a job or you live without a wheelchair. That isn't much of a choice. ${ }^{23}$

\section{Education}

Close to $8 \%$ of children under age 15 , more than 4.6 million children in all, have at least one physical or mental disability. ${ }^{24}$ Over a third of

${ }^{18}$ See supra note 14.

${ }^{19} \mathrm{Id}$.

${ }^{20}$ See supra note 7 . This figure was also reported in a summary of the Work Incentives Improvement Act of 1999 on Representative Henry Waxman's website at http://www.house.gov/waxman/issues/health/issues_hcalth_work_incentive_3_18_99.htm (last visited Dec. 12, 2002).

21 There are strict financial eligibility criteria for this program that people with disabilities who work may exceed. Eligibility for Medicare and Medicaid also requires analysis of a person's income. Because these programs provide substantial health care coverage for people with disabilities, it is the fear of losing this coverage that prevents some people with disabilities from seeking work. Even if a person qualifies for employer-sponsored health care coverage, Medicare and Medicaid will often finance necessary expenses that private insurance companies will not, so fear of losing this coverage is a powerful disincentive to seeking work. It should be noted, however, that both SSI and SSDI do include significant incentives and support for people wishing to return to work. These special provisions are described in the second part of this article.

22 The Ticket to Work and Work Incentives Improvement Act (TTWWIIA) was designed to address this very important problem and has had some success at increasing employment among people with disabilities. We deal with this legislation in detail in the next section of the article.

${ }^{23}$ Mike Ervin, New bill will not change much for people with disabilities, Progressive Media Project, (Jan. 10, 2000), available at http://www.progressive.org/pmpjfm00.html (last visited Dec. 12, 2002).

24 Centers for Disease Control, Attention Deficit Disorder and Learning Disability: United States, 1997-98, $10 \mathrm{Vital}$ and Health Statistics 206 (2002), available at http:// www.cdc.gov/nchs/products/pubs/pubd/series/sr 10/pre-200/pre-200.htm. (last visited Dec. 12, 
these children have Attention Deficit Disorder (ADD) or a Learning Disability (LD) that specifically affects their ability to participate in the classroom. ${ }^{25}$ Like their counterparts without disabilities, children with disabilities are entitled to a free, appropriate public education. However, children with disabilities often need modifications to participate in classroom education, and in some cases they cannot participate in regular classrooms at all. Thus, alternative educational environments and strategies need to be developed for these children, often on an individual basis.

\section{Health Care}

Access to health care services, including mental health and substance abuse services and prescription drugs, is a perennial problem for people with disabilities. The HIV/AIDS epidemic also has created an entirely new class of people with disabilities, and with it a set of problems that must be addressed by programs and services, as well as the legal system.

\section{Insurance}

Among the services and accommodations that are necessary for people with disabilities, access to quality affordable health care is perhaps the most important. While health care in general represents a large and growing proportion of the total public and private resource expenditure in the United States (approximately 15\% of the GDP), Americans with disabilities are in poorer health ${ }^{26}$ and have relatively greater health care needs (and therefore larger expenditures for health care services) than those who are not currently experiencing disability. It is clear that in an employment-based insurance system, like the one in the United States, disability is a significant impediment to access to health insurance. Over $17 \%$ of people with disabilities have no health insurance at all, either public or private. ${ }^{27}$ While there are some private insurance companies that provide health benefit plans to people with disabilities, people with disabilities have $50 \%$ of their health care paid for by public

2002).

${ }^{25} \mathrm{Id}$.

${ }^{26}$ According to the U.S. Census Bureau statistics for 1997 , only $14.5 \%$ of people with severe disabilities report good or excellent health, compared to $58.9 \%$ who report poor or fair health.

${ }^{27}$ This figure is for people less than 65 years old. According to U.S. Census Bureau statistics for $1997,99 \%$ of all U.S. citizens over 65 have health insurance coverage under Medicare. 
sources such as Medicare and Medicaid. ${ }^{28}$ In order to qualify for Medicare and Medicaid, people with disabilities must meet the eligibility requirements for Social Security Disability Insurance (SSDI) and Supplemental Security Income (SSI) as described in the second part of this article. As the above figure indicates, $50 \%$ of people with severe disabilities have private health care coverage, but in comparison to the health care coverage of those people who are not disabled (82\%), this figure is remarkably low.

\section{Access to Prescription Drugs}

People with disabilities are more likely to require prescription drugs than those without disabilities. ${ }^{29}$ They are also more likely to have multiple prescriptions and to experience greater complications, such as worsened symptoms, when they are not able to get their prescriptions filled. Because prescription drugs represent a large portion of disabled people's health care spending, and because the price of those drugs is rapidly increasing, access to adequate prescription drug coverage is a major issue in disability research and policy. ${ }^{30}$

\section{Mental Health}

In 1997, 14.3 million people in the United States had some form of mental health problem. ${ }^{31} 1.4$ million were mentally retarded, 1.9 million had Alzheimer's Disease and 7 million had a learning disability or other emotional or mental condition. Of this latter category, 5.6 million had been diagnosed with clinical depression.

In 1994, the most recent statistics available from the National Center for Health Statistics, \$33 billion was spent on treatment and services for the mentally ill. ${ }^{32}$ Only $37 \%$ of people with mental health problems were employed. However, a recent study has shown that when people with mental disorders work, they are as productive, in

${ }^{28}$ See supra note 7.

${ }^{29}$ Jae Kennedy and Christopher Erb, Prescription Noncompliance due to Cost Among Adults With Disabilities in the United States, 92(7) American Journal of Public Health $1120-1124$.

${ }^{30} \mathrm{~S}$. Soumerai and D. Ross-Degnan, Inadequate Prescription-Drug Coverage for Medicare Enrollees-A Call to Action, 340(9) NEw ENGLAND JOURNAL OF MEDicine 722-728 (1999).

${ }^{31}$ See supra note 14.

32 National Institutes of Health, Table 125: Mental Health Expenditures, percent distribution, and per capita expenditures, according to type of mental health organization: United States, selected years 1975-94, available at http://www.cdc.gov/nchs/products/ pubs/pubd/hus/tables/2001/01 hus125/pdf (last visited Dec. 12, 2002). 
terms of absenteeism and at-work productivity, as those employees who do not have a mental illnesses, provided that they are receiving adequate treatment for their mental health problems. ${ }^{33}$ This suggests that a policy that focuses on adequate treatment for mental illness may be the most effective at increasing employment and productivity among people with mental disorders.

\section{HIV/AIDS}

The Centers for Disease Control estimates that approximately 800,000 to 900,000 people are currently infected with Human Immunodeficiency Virus (HIV) in the United States, with roughly 40,000 new cases reported annually. ${ }^{34}$ Many of these people lack health insurance and financial resources to pay for their care. As a result, more than 530,000 people with Acquired Immune Deficiency Syndrome (AIDS) receive supportive funding from programs established by the Ryan White CARE Act, ${ }^{35}$ a federal program designed to help fund HIV/AIDS related services for low-income and uninsured people with HIV disease.

The complications of AIDS, including its effects on people's ability to work, engage in recreation and reproduce, can be overwhelming. An important recent trend in the United States is that the HIV/AIDS epidemic is increasingly affecting women, minorities, persons infected through heterosexual contact, and the poor. ${ }^{36}$ In addition, the social stigma of being HIV positive continues to isolate people from the communities in which they live and subject them to discrimination because of their illness. This discrimination is becoming more problematic for people as treatment becomes more effective. HIV infection has become a chronic illness in many cases, and does not necessarily prevent a person from seeking employment and social services. However, now that HIV positive people are able to

${ }^{33}$ Berndt, Health Care Use and At-Work Productivity Among Employees with Mental Disorders, 19(4) Health AFFaiRs 244-256 (2000).

${ }^{34}$ Centers for Disease Control and Prevention, HIV/AIDS Update, (2000), available at http://www.cdc.gov/nchstp/od/news/hiv_key_findings.html (last visited Dec. 12, 2002).

${ }^{35}$ The Ryan White Comprehensive AIDS Resources Emergency Act (PL 106-345) was originally enacted in 1990 as an initiative to fund primary care and support services for people living with HIV disease. The Act was reauthorized in 1996 and again in 2000 for a five-year period. For more information about the Ryan White CARE Act and the programs it established, see U.S. Dep't of Health and Human Services, HIV/AIDS Bureau, http://www.hab/hrsa.gov/history.htm (last visited Dec. 12, 2002).

${ }^{36}$ John Karon et al., HIV in the United States at the Turn of the Century: An Epidemic in Transition, 91(7) AM. J. OF Public Health 1060-1068 (2001). 
return to the workforce at higher rates, many have encountered a renewed level of discrimination.

\section{Technology}

Recent technological advances represent a significant opportunity for people with disabilities who otherwise would be limited in their ability to access public and commercial services. For example, the CDC estimates that approximately 17 million Americans use assistive devices to help with mobility, orthopedic, hearing and vision problems. ${ }^{37}$ In addition, the Internet holds great promise for people with disabilities who could use their computers to shop and interact socially without leaving their home. With adequate support, many people with disabilities could work from home more efficiently and economically than they could work in a traditional business setting. However, according to a recent report sponsored by the National Institute on Disability and Rehabilitation Research (NIDRR), people with disabilities are only half as likely to have a computer at home as the general population $(23.9 \%$ compared to $51.7 \%)$. ${ }^{38}$ Only $26.2 \%$ of people with disabilities who have a computer actually use it for work, compared to $43.1 \%$ of the non-disabled. This may be because as many as $98 \%$ of websites are inaccessible to people with disabilities. ${ }^{39}$

\section{Foundations of Disability Policy}

Disability policy in the United States is founded on a framework of programs and services, as well as laws and regulations, which support the public policy goal of eliminating barriers and facilitating opportunities for people with disabilities. Over the years, a network of support services has developed that is increasingly comprehensive in scope. Periodically, the scope has been expanded, and the gaps filled

37 Center for Disease Control and Prevention, Nat'l Center for Health Statistics, Disabilities and Impairments (1994), available at http://www.cdc.gov/nchs/fastats/disable.htm (last visited Dec. 12, 2002).

${ }^{38}$ Stephen H. Kaye, Disability Statistics Report, Computer and Internet Use Among People with Disabilities, U.S. Dep't of Educ., pp. 13 (2000).

${ }^{39}$ The estimate of $98 \%$ is from the article by Sally McGrane, Is the Web Truly Accessible to the Disabled?, CNET, (Jan. 26, 2000), at http://www.cnet.com/specialreports/0-6014-71530074.html. Other sources list a lower figure. Regardless of the exact percentage, there is wide agreement that at least three quarters of all Web pages are currently inaccessible to people with disabilities. See, e.g., The Web Accessibility Survey, http://library.uwsp.edu/aschmetz/ Accessible/websurveys.htm (last visited Jan. 3, 2003), Bobby, http://www.cast.org (last visited Jan. 3, 2003), and the W3C homepage, http://www.w3c.org (last visited Jan. 3, 2003). 
in, by additional regulation and modification of services. In this section, we outline the major programmatic and legal foundations of disability policy.

\section{Programs and Services}

There are four major federal programs that provide cash benefits or health care coverage to people with disabilities. ${ }^{40}$ While roughly $50 \%$ of total enrollment in public assistance programs is by people with disabilities, more than $75 \%$ of people with disabilities aged 22 to 64 years do not receive any kind of public assistance. These figures reveal the mixed blessing of public services for people with disabilities. First, the fact that $75 \%$ of people with disabilities do not receive public assistance may be a good sign because it suggests that they are financially self-sufficient and earning adequate incomes to support their needs. In fact, many of people with non-severe disabilities have private insurance (approximately 80\%), which they receive through their employer. However, these figures also reveal that many people who could benefit from financial and other services are left out because of difficulties in qualifying for programs. There are a significant number of people with disabilities who are part of the workforce (they are capable of working and seeking work) but who are nonetheless unemployed. $^{41}$ The goal of public assistance programs is to provide a safety net for those who do not qualify or cannot afford private, employment-based insurance.

\section{Supplemental Security Income (SSI)}

SSI is a need-based program that provides cash benefits to people with disabilities whose monthly income and total countable assets (excluding the value of a house and other personal effects related to daily living) are below a specified threshold level. The specific threshold is indexed to cost of living in the potential beneficiary's home state and the payment may be supplemented by the state. ${ }^{42}$ Eligibility

40 Other programs exist, such as tax credit programs for businesses that make accommodations for people with disabilities, but they are minor in both scope and funding in comparison to the four presented here.

${ }^{41}$ In 1996, $13.4 \%$ of the 5.4 million workforce participants with work disabilities were unemployed. For more on disability and employment see supra note 20.

${ }^{42}$ In 2002, the federal minimum threshold was a monthly income of less than $\$ 531$ and total assets less than $\$ 2,000$. Some states supplement the federal contribution by adding directly to the payment, while others administer a separate program that requires a second application. 
for SSI also qualifies a person for Medicaid. Currently, 3.8 million adults with severe disabilities aged 18 to 64 receive SSI cash benefits. ${ }^{43}$ This is a slight increase from the 1997 figures, when 3.4 million people with severe disabilities received SSI benefits. ${ }^{44}$ Overall, about $20 \%$ of people with severe disabilities qualify for SSI, and this number has not changed much in the last decade. SSI also provides special work incentives for those who are capable and wish to work. These include provisions such as: 1) loss of cash benefits does not result in loss of Medicaid, ${ }^{45}$ 2) treatment of employment-related work expenses ${ }^{46}$ and 3 ) plan to achieve self support. ${ }^{47}$

\section{Social Security Disability Insurance (SSDI)}

SSDI provides long term benefits to disabled workers beginning with the sixth month of work preventing disability. Beneficiaries must be severely disabled, as defined by the $\mathrm{SSA},{ }^{48}$ and eligibility is tied to employment history and benefits are paid in proportion to the lifetime annual average income. Currently, SSDI pays a monthly benefit ${ }^{49}$ to 5.1 million workers with disabilities and 1.6 million of their qualified family members. People who qualify for SSDI also are eligible for Medicare benefits. Participation in the Social Security Disability Insurance Program increased by $160 \%$ between the mid-1980s and 1996 from 4.4 million to 7.1 million enrollees before it dropped slightly to its current level of 6.7 million. About $9.5 \%$ of people with disabilities are covered under SSDI, which is less than one third of all people with severe disabilities. Like SSI, SSDI also provides important incentives for returning to work, including: 1) indexing of the amount considered substantial gainful activity, 2) a trial work period and 3) an extended period of eligibility.

\section{Medicaid}

This need-based, federal-state health insurance program covers most medical expenses for people with disabilities, including doctors' visits, prescription drugs and long term care in assisted-living facilities. Some

${ }^{43}$ The Social Security Administration, Fact Sheet on Social Security Disability and Supplemental Security Income (2002)

${ }^{44}$ See supra note 14.

${ }^{45} 20$ C.F.R $\$ \$ 416.260-69$

${ }^{46} 20$ C.F.R. $\$ 416.976$

${ }^{47} 20$ C.F.R. $\$ 416.1112 ; 20$ C.F.R. $\$ \$ 416.1180-81$

${ }^{48}$ See supra notes 9 and 11.

${ }^{49}$ The average monthly payment for an individual in 2002 is $\$ 815$ 
states provide a "medically needy" eligibility category for people whose income excludes them from SSI participation. In this case, individuals can "spend-down" their excess income by incurring medical or remedial care expenses, at which time they become eligible for assistance under Medicaid. ${ }^{50}$ About a third (32.5\%) of severely disabled people aged 25 to 64 , or 5.3 million, are currently enrolled in Medicaid programs. About 800,000 , or $4.8 \%$, of people with nonsevere disabilities are Medicaid beneficiaries. ${ }^{51}$ In 2001, Medicaid paid $\$ 49$ billion for people with disabilities. Medicaid also supports 240 state home and community-based service programs for people with disabilities that provide alternatives to institutional care, such as home care. Some people with disabilities do not qualify for Medicaid because of their incomes, but remain without health insurance coverage because their employers do not provide it. This is the case for about $17.3 \%$ of people with disabilities. ${ }^{52}$

\section{Medicare}

Some people with disabilities also qualify for the federal Medicare program. Eligibility for Medicare requires that a person first be enrolled in the SSDI program for at least 24 months prior to enrollment in Medicare. Because of this requirement, participation in Medicare is tied to a person's work history, and a person who has never been able to work because of his disability cannot receive Medicare benefits. As with SSDI, eligibility for Medicare requires that a person have a severe disability as defined by the SSA. ${ }^{53}$ Over four million, or $25.6 \%$ of people with severe disabilities aged 25 to 64 are currently enrolled in Medicare. ${ }^{54}$ This represents about $12 \%$ of the roughly 40 million current Medicare beneficiaries. Some $\$ 32$ billion was spent in 2001 for disabled Medicare beneficiaries. Part A of Medicare covers hospital expenses and some nursing home care, but does not currently provide a prescription drug benefit. People with disabilities can also purchase a Part B plan to help pay for additional health care services that are not

so Centers for Medicare and Medicaid Services, Medicaid Eligibility, at http://cms.hhs.gov/medicaid/eligibility/criteria.asp (last visited Jan. 10, 2003).

${ }^{51}$ See supra note 14.

${ }^{52} \mathrm{Id}$.

${ }^{53}$ See supra notes 9 and 11.

${ }^{54}$ See supra note 14. 
covered in Part A. ${ }^{55}$ About $5 \%$ of people with disabilities have a Medigap plan that provides coverage for prescription drugs. ${ }^{56}$

\section{Laws and Regulations}

The most well known of the disability rights laws, The Americans with Disabilities Act of 1990, is but one of over a dozen major federal laws that provide protections and services for people with disabilities. ${ }^{57}$ The history of this body of legislation is interesting in that there were several incremental and influential steps leading up to the passage of the ADA in 1990, and there have been several significant additional laws passed since then in areas that were not addressed sufficiently by the ADA. The group of laws protecting the rights of people with disabilities is large and wide-ranging. It includes protections and services for people with disabilities in all major areas of life, including employment, education, health care, accessibility, technology and taxes. This section describes the evolution of legal protections for people with disabilities over time and provides an overview of the provisions of major disability rights laws. ${ }^{58}$

\section{Fair Housing Act of 1968}

The Fair Housing Act (FHA ${ }^{59}$ was amended in 1988 to extend federal civil rights protections to people with disabilities in the sale and rental of private housing, housing that receives federal financial assistance, and state and local government housing. ${ }^{60}$ The act's major provisions

${ }^{55}$ Smith, Sharon, Sleep Disorders and Disability: Part II: Types of Disability Programs and their Requirenents (2002), at http://www.talkaboutsleep.com/disability/Disability Part2.htm (last visited Dec. 12, 2002).

${ }^{56}$ Medigap plans are private health insurance plans that can be purchased at a premium to help cover additional services not covered by Medicare Parts A and B, such as prescription drugs. See, e.g., Department of Labor, Overcoming obstacles to employment of people with disabilities, available at http://www.dol.gov/_sec/public/programs/ptread/9_22_rpt.htm (visited Dec. 12, 2002).

${ }_{57}$ U.S. Dep't of Justice, A Guide to Disability Rights Laws, at http://www.usdoj.gov/ $\mathrm{crt} /$ ada/cguide.pdf (last visited Dec. 12, 2002).

58 Other laws not covered in detail here include: Air Carrier Access Act, Voting Accessibility for the Elderly and Handicapped Act, Nat'! Voter Registration Act, Civil Rights of Institutionalized Act, Architectural Barriers Act, Television Decoder Circuitry Act. These laws address a variety of functional issues for people with disabilities and serve to clarify or enhance the major laws.

${ }^{59} 42$ U.S.C. $\$ \$ 3601$ et. seq.

${ }^{60}$ The FHA was originally passed in 1968 as Title 8 of the Civil Rights Act. Prior to 1988, however, the FHA did not recognize people with disabilities as a group in need of protection in housing-related issues. 
apply to landlords' activities and to zoning and land-use regulations. According to the FHA's provisions, landlords are required to make reasonable exceptions to their policies and operations to afford people with disabilities equal housing opportunities. Such exceptions may involve waving a "no pet" rule for an individual who is blind and uses a guide dog, or allowing the tenant to make access-related modifications to their living space. As it applies to people with disabilities, FHA prohibits zoning or land-use decisions on the part of local governments that discriminate against people with disabilities, and requires "reasonable accommodations" in zoning and land use laws where it is necessary to provide housing for people with disabilities, such as would be the case in allowing group homes for people with disabilities in residential neighborhoods.

\section{The Rehabilitation Act of 1973}

The Rehabilitation Act prohibits discrimination against people with disabilities by federal agencies, programs receiving federal funding and federal employment programs. It also applies at the state and local levels. Under the Act, Vocational Rehabilitation (VR) programs must be made accessible to people with disabilities, and Individualized Plans for Employment (IPEs) must be drafted for each individual in an employment program. The Act's four relevant sections deal with various aspects of government operations. Section 501 applies to the Executive Branch, ${ }^{61}$ Section 503 to entities that have federal government contracts of $\$ 10,000$ or more ${ }^{62}$ and Section 504 , which is the broadest section, applies to all federal agencies or programs receiving federal funding, including public schools. Section 504 was the precursor to IDEA and is still used to provide educational assistance and accommodations for children with disabilities who are not eligible for IDEA services. In addition to the important education component, 504 also focused on providing equal access to government services and programs for people with disabilities. Each agency must develop its own set of 504-based regulations to make reasonable accommodations, program accessibility, effective communication and accessible new construction. $^{63}$ Section 508 applies to technology and electronic services used by the federal government, which must be accessible to

\footnotetext{
6129 U.S.C. $\$ 791$.

6229 U.S.C. $\$ 793$.

6329 U.S.C. $\$ 794$.
} 
employees and the public and able to be operated in a variety of ways. $^{64}$. The 1998 amendments to section 508 require, for example, that federal government agencies have accessible web sites except where doing so would impose an undue burden on the agency, in which case the same information must be made available via other means.

\section{The Americans with Disabilities Act of 1990}

As a civil rights law, The Americans with Disabilities Act of 1990 covers a wide range of issues concerning people with disabilities. Its Titles, while generally designed to categorically prevent discrimination against people with disabilities, focus on four specific aspects of life, including access to: 1) employment, 2) public accommodations, 3) public services and transportation, and 4) telecommunications services. Title I deals with access to employment by people with disabilities by requiring that businesses with fifteen or more employees provide reasonable accommodations to workplace environments and job descriptions for qualified people with disabilities. This Title also regulates employer hiring practices and wage and benefit structures, which cannot place uneven burdens on people with disabilities, such as would be the case if people with disabilities were required to pay higher premiums for health insurance coverage or undergo a medical assessment prior to employment if that were not a requirement for all potential employees. ${ }^{65}$ The Equal Employment Opportunity Commission (EEOC) is charged with implementing Title I regulations.

Title II deals with all aspects of state and local government activities and with public transportation. Under Title II, government activities, including education, employment, transportation, recreation, health care, social services, courts, voting and town meetings must be accessible to people with disabilities. Also targeted under Title II are transportation services, which include commuter and rail services as well as public bus systems that are provided by state and local governments. Private transportation services that are for hire to the general public must also conform to Title II regulations. ${ }^{66}$

Title III addresses access to public accommodations, and prohibits exclusion, segregation and unequal treatment of people with disabilities. Under this Title, all new construction and alterations to

${ }^{64} 29$ U.S.C. $\$ 794 d$.

${ }^{65} 42$ U.S.C. $\$ 12101$ et. seq; 29 C.F.R. $\$ \$ 1602,1630$.

66 Title II implementing regulation, 28 C.F.R $\S 35$; Titles II and III Impl. Regs., 49 C.F.R. $\$ 27,37,38$ 
public buildings and areas must be accessible to people with disabilities and barriers to access must be removed from existing facilities if doing so is readily achievable. Entities covered under Title III include all private people or groups who own, lease or operate facilities that are open to the public. Churches and private clubs are not regulated by Title III. ${ }^{67}$ The Departments of Justice and Transportation are in charge of implementing and enforcing both Title II and Title III regulations.

Title IV applies to telecommunications services and requires telephone companies to provide telephone relay services to people who use teletypewriters (TTYs). ${ }^{68}$ Title IV is enforced by the Federal Communications Commission (FCC). Title V serves as a safety net for individuals who bring action under the first four Titles. Its major provision prohibits retaliating against, coercing or threatening people with disabilities or their advocates when they attempt to assert their rights under the $\mathrm{ADA}$.

\section{The Individuals with Disabilities Education Act of 1990}

The Individuals with Disabilities Education Act (IDEA) ${ }^{69}$ was created in 1990 as a reauthorization of the Education for All Handicapped Children Act of 1975. The Act requires that states provide a free and appropriate public education to children age 3 to 21 years old who have a disability. The required services, which must be provided at public expense, include special education and related services provided in the least restrictive environment appropriate to each child's individual needs. The IDEA was amended in 1997 to address evolving issues in education policy. The amendments strengthen expectations and accountability for children with disabilities and their teachers and schools in several ways. Specifically, the revisions increased parental involvement, emphasized placement into the least restrictive setting, required that students with disabilities be taught the general curriculum where appropriate and addressed concerns about minority children being disproportionately placed in more restrictive learning environments. It also requires public schools to develop an appropriate Individualized Educational Plan (IEP) for each qualified child. The IEP is a written document that draws on input from the special

${ }^{67}$ Titles II and III Impl. Regs., 49 C.F.R. $\S \S 27,37,38$; Title III Impl. Reg, 28 C.F.R. $\S$ 36.

\footnotetext{
${ }^{68}$ Title IV Impl. Reg., 47 C.F.R. $\S \S 64.601$ et. seq.

${ }^{69} 20$ U.S.C. $\S \S 1400$ et. seq.
} 
education teacher, the parents, specialists and the child's general curriculum teacher. It outlines academic goals and milestones for the student, which take into account the disability and its severity. The IDEA also requires that the child be placed in the least restrictive setting appropriate to his individual needs, and it provides grants to states to assist in the development of special education programs for children with disabilities. In the 1997 revision to the IDEA regulations, Attention Deficit Disorder (ADD) and Attention Deficit Hyperactivity Disorder (ADHD) were added to the list of disorders that are potentially eligible for services under IDEA. This addition was prompted in part by the fact that children with learning disabilities such as these accounted for $50 \%$ of the children covered by the Act.

\section{Mental Health Parity Act of 1996}

The Mental Health Parity Act (MHPA) ${ }^{70}$ was signed into law as part of the Health Insurance Portability and Accountability Act of 1996. People with mental health conditions had been subjected to more restrictive benefits limitations for their mental health care than for other medical and surgical care. Under the MHPA, public and private health insurance companies, including managed care organizations, are prohibited from setting lower annual or lifetime dollar limits on mental health benefits than are provided for physical health benefits. This federal law did not require that insurance companies or employers provide mental health benefits, but if they chose to, they were required to comply with the law. There were no restrictions, however, on other forms of benefits limitations, such as the number of visits to a psychiatrist that were covered or the amount a beneficiary was required to pay as a co-payment at each visit. Substance abuse services also were not covered under the federal law. Nor did it provide for vocational services for people with mental health disabilities. ${ }^{71}$ To fill in some of these apparent gaps in the federal legislation, many states have passed Mental Health Parity laws, often with more comprehensive regulations of benefit plans.

By 2001, more than thirty states had passed some form of mental health parity law. State responses to mental health insurance regulation have been mixed. The most common variable among state parity laws is whether mental health benefits are mandated or whether they are

\footnotetext{
${ }^{70}$ Pub. L. No. 104-204.

${ }^{71}$ Id.
} 
optional but regulated. Twenty-three states have passed laws mandating parity in mental health coverage; twenty-four states have mandated benefits laws; seventeen states have mandated offering laws. $^{72}$

\section{Work Incentives Improvement Act of 1999}

The Ticket to Work and Work Incentives Improvement Act (TWWIIA) was designed to address the problem that many people with disabilities lose their publicly-financed health care benefits when they return to work. For many people with disabilities who work, their employer either does not offer a health care plan, or the plan is not adequate or is too expensive for their needs. TWWIIA addresses two major issues for people with disabilities who desire to work: access to adequate, affordable health care services and assistance in finding and being successful in a new job. Its major goal is to facilitate people's choice to return to work by eliminating some of the most potent barriers. This was to be done through expanding Medicare and Medicaid options, as well as with grants to encourage States to establish programs.

The Act includes both health care coverage and employment assistance provisions. It expands the Medicaid program in two ways: it creates a "buy-in" option for people with disabilities who work whose income is still below $250 \%$ of the FPL and it contains a "medical improvement" clause for people with disabilities who are healthy enough to work but still require significant medical support to do so. To assist states in providing this Medicaid expansion, the Act authorizes infrastructure grants to states. Congress allotted $\$ 150$ million for the first five years of the program, and by May 2002, thirtyeight states had received Medicaid Infrastructure Grants under the TWWIIA. ${ }^{73}$ The Act also allows people with disabilities to continue their Medicare coverage for up to four years after returning to work.

${ }^{72}$ A typical "mandated parity" law requires that insurance companies set equal financial limits on mental health and medical and surgical benefits, if offered, but it does not require companies to provide mental health benefits. "Mandated benefits" laws require that insurance companies provide at least a basic benefit for mental health in all their insurance plans, and "mandated offering" laws require insurance companies to offer those benefits to employers for purchase; the employer is not required to pay for that bencfit package for its employees. For more on parity laws in specific states, see Nat'l Conference of State Legislatures, 2001. State laws mandating or regulating mental health benefits, at http://204.131.235.67/programs/ health/Mentalben.htm (last visited Dec. 12, 2002).

73 U.S. Dep't of Health and Human Services, Factsheet: HHS Programs Serve Americans with Disabilities, available at http://www.hhs.gov/topics/disabilities.html (May 2002). 
The Ticket to Work and Self-Sufficiency programs provide employment training, vocational rehabilitation (VR) services, and other support services to people with disabilities. These programs give people with disabilities a choice of public and private VR service providers, provide outreach and assistance services to provide information and reduce paperwork, and create demonstration projects for states to study optimal benefit levels and schedules for people with disabilities who are working. These demonstration projects were supported with $\$ 250$ million over the first six years of the program.

\section{Technology-Related Laws}

There is no one law or regulation that controls all aspects of technology-related issues for people with disabilities. Instead, a variety of technology-related laws make up the legal foundation in this area. Beginning with the Technology-related Assistance Act for Individuals with Disabilities Act of $1988,{ }^{74}$ a series of laws were designed to help support people with disabilities' access to technological services, including the Television Circuitry Decoder Act of $1990,{ }^{75}$ the Telecommunications Act of $1996,{ }^{76}$ the Assistive Technology Act of $1998^{77}$ and the Workforce Investment Act of 1998, which was later codified as Section 504 of the Rehabilitation $\mathrm{Act}^{78}$. These laws require federal and state governments, businesses and telecommunications service providers to make their services accessible to people with disabilities.

\section{LEGAL INTERPRETATIONS OF DISABILITY ISSUES}

In fiscal year 2001 alone, there were 16,470 ADA Title I and Title V cases filed in United States courts. This number was down slightly from five years earlier when over 18,000 cases were filed. In 2001, monetary awards under ADA cases totaled $\$ 47.9$ million, and since 1990 the total monetary awards have been $\$ 346$ million for a total of

${ }^{74}$ S. 2561, 100th Cong. (1988), available at http://www.resna.org/taproject/library/laws/ techact88. htm (last visited Jan. 10, 2003).

75 Television Decoder Circuitry Act of 1990, S. 1974, 101st Cong. (1990), available at http://www.ncicap.org/Docs/dcb.htm (last visited Jan. 10, 2003).

${ }^{76}$ See Federal Communications Comm'n, Telecommunications Act of 1996, available at http://www.fcc.gov/telecom.html (last visited Jan. 10, 2003).

${ }^{77}$ S. 2432, available at http://www.section508.gov/docs/AT1998.html (last visited July 7, 2002).

${ }^{78} 29$ U.S.C. \$ $794 \mathrm{~d}$. 
158,280 cases filed $^{79}$. The majority of these cases were closed for "no reasonable cause" (53\% overall for the decade 1992-2001), and of the cases in which reasonable cause was found $(6.1 \%)$, only $2 \%$ resulted in rulings in favor of the plaintiff. ${ }^{80}$ Over this decade-long period, $20 \%$ of these Title I cases were filed on the basis of mental or cognitive impairment such as depression, learning disabilities and Alzheimer's disease, $22 \%$ for medical conditions such as diabetes, cardiovascular disease, and cancer, and $35 \%$ because of physical impairment such as vision and hearing disorders and orthopedic injuries. The remaining $23 \%$ of cases were registered as non-specified disability or cases relating to people who had a record of a disability or who were regarded as having a disability. While the Supreme Court has dealt primarily with cases brought under the ADA, it also heard several important IDEA cases in the 1990s. We also summarize these IDEA cases under our analysis of educational issues for people with disabilities.

Attention to the Supreme Court's interpretation of disability rights law is critical because it is here that these laws become functional and their validity, scope and power are tested. By their nature, the Supreme Court's rulings affect how the law is interpreted and applied by businesses, program administrators and lower courts. In the following discussion, we describe the trends in Supreme Court decision-making in disability-related cases since the passage of the ADA. We present several cases that illustrate these trends and summarize the Court's reasoning in each case. In just the last four years, the Supreme Court has ruled on eight major ADA cases interpreting the employment discrimination portions of the ADA. Three of these cases were decided early in 2002.

In order to state a claim under the ADA, a plaintiff must establish: 1) that he is disabled within the meaning of the ADA, 2) that he is qualified, with or without accommodation, to perform the essential functions of the job and 3) that the employer terminated him because of his disability. The past decade has seen a shift in the Supreme Court's

${ }^{79}$ U.S. Equal Emp. Opportunity Comm'n, Americans with Disability Act of 1990 (ADA Charges) FY 1992-FY 2001, at http://www.eeoc.gov/stats/ada-charges.html (last visited Jan. 10, 2003). The EEOC administers the implementation of Titles I and V of the ADA, and is in charge of their enforcement. The numbers presented here represent the total of charges that the EEOC has received under Titles $I$ and $V$, and do not include charges or awards under ADA Titles II, III, or IV.

${ }^{80}$ For a more detailed accounting of ADA Titic I and $V$ charges and to see trends, see infra note 79 
approach to handling ADA cases. Early in the 1990s, the court allowed a per se definition of disability, assuming for the purposes of the case that the plaintiff was indeed disabled. These early cases turned accordingly on whether a person with a disability had been discriminated against on the basis of his disability. This trend began to change in the middle of the 1990s and has continued to move toward a more detailed individualized assessment of a person's disability status. Recent decisions have hinged on whether a person has a disability at all rather than whether discrimination has occurred because of a disability. The Court's detailed analysis focuses instead on two areas: 1) whether the person is impaired in such a way that prevents him from performing his job; and 2) whether the impairment "substantially limits" a "major life activity" other than work.

In seven of the eight most recent (1998-2002) ADA Title I cases, the Court has found the arguments of businesses more convincing than those of the plaintiffs, and has progressively narrowed the avenues of protection that people with disabilities have under the ADA. ${ }^{81}$ These cases clearly put the burden of proof on a person who brings a claim under the ADA. In the future, businesses may be able to show any number of "typical business practices" to make them exempt from making accommodations to people with disabilities under the ADA. If so, we may see disabled people's ability to move into and remain in the workforce diminished even further. The most recent ADA case further suggests that this is true, although with an entirely new twist. Our presentation of these cases is organized according to their relationship to each of the ADA Titles and the IDEA.

\section{ADA Title I}

Title I of the ADA applies to discrimination in the workplace. The Supreme Court heard eight Title I cases between 1998 and 2002. Four of the cases dealt with the ADA's definition of disability and what standard should be used to decide whether a person is a "qualified person with a disability" under the ADA.

Another set of cases dealt with what constitutes a "reasonable accommodation" that employers must make under the ADA. A final case dealt with whether an employer can refuse to hire a person with a

\footnotetext{
${ }^{81}$ In the eighth case, Cleveland v. Policy Management Systems Corp, the Supreme Court didn't rule on the issue of disability. Rather, it clarified whether the claim was eligible under the ADA. Finding that it was, the Court remanded the case to the lower court to decide on the individual merits of Cleveland's argument. 526 U.S. 795 (1999).
} 
disability if doing so would pose a threat to that person's own health or safety.

\section{Sutton et al. v. United Airlines, Inc. (Sutton), ${ }^{82}$ Murphy v. United Parcel Service, Inc. (Murphy) ${ }^{83}$ and Albertsons v. Kirkingburg (Kirkingburg) $^{84}$}

The Sutton Trilogy, as these cases are known, examined the definition of disability under the $\mathrm{ADA}$, particularly to address the role of corrective measures such as eyeglasses in determining whether a person is substantially limited in a major life activity. In these three 1999 cases, the Court concluded that if a disability can be corrected to the point that it no longer interferes with normal life activity, then the person with that disability no longer qualifies for protection under the ADA.

In Sutton and Kirkingburg, the disability was vision, correctable with glasses. ${ }^{85}$ In Murphy, the disability was hypertension, correctable with medication. ${ }^{86}$ The Supreme Court concluded that because their disabilities did not limit one or more major life activities when they were accompanied by mitigating treatment -- the definition of disability under the ADA -- the plaintiffs were not entitled to the ADA's protection. ${ }^{87}$ The Court reasoned, for example, "Looking at the Act as a whole, it is apparent that if a person is taking measures to correct for, or mitigate, a physical or mental impairment, the effects of those measures -- both positive and negative -- must be taken into account when judging whether that person is 'substantially limited' in a major life activity and thus 'disabled' under the Act." 88 That requirement would include showing that the impairment affected a greater range of

\footnotetext{
${ }^{82}$ Sutton, et. al. v. United Airlines, Inc., 527 U.S 471 (1999).

${ }^{83}$ Murphy v. United Parcel Service, Inc. 527 U.S. 516 (1999).

${ }^{84}$ Albertsons, Inc. v. Kirkingburg. 527 U.S. 555 (1999).

${ }^{85}$ See Sutton, 527 U.S. at 476; Kirkingburg 527 U.S. at 559.

${ }^{86}$ See Murphy 527 U.S. at 519.
}

${ }^{87}$ The EEOC guidelines, which the lower court had relied on in its decision, state that regardless of the correction or lack thereof of a disability, any impairment that interferes with one of more major life activities is a disability. The EEOC definition of disability is more broad than the interpretation the Supreme Court is making of the ADA's language in Sutton. According to the Supreme Court's interpretation, however, Congress did not intend for EEOC to be able to override the ADA language, and the Court overruled the EEOC in favor of a textual reliance on the ADA. The Supreme Court is saying in the Sutton Trilogy that corrective devices that mitigate the impairment must be considered and that, if correctable, a person is not qualified person with a disability under the ADA.

${ }^{88}$ Sutton, 527 U.S. at 482. 
life activities than those required for a particular job, and that that range of activities was something that the general population would regard as being major life activities. In Sutton, the plaintiffs were airline pilots, and the Court reasoned that, since there were other jobs that would utilize the sisters' skills available, excluding them from being pilots did not inhibit them from engaging in a major life activity. ${ }^{89}$ The sisters could find other jobs.

With its decisions in the Sutton Trilogy, the Supreme Court began to scrutinize the definition of disability under the ADA. In doing so, it has ruled that a significant group of people with physical and mental impairments may not be considered disabled under the ADA. As a result, a person whose impairment is treatable may still experience some form of discrimination because of his disability status, but it appears that this will no longer be qualified for protection under the ADA when it occurs. ${ }^{90}$ Another 1999 case, Cleveland, raised a related issue: if a person is so disabled that she cannot work, is she still qualified to bring a claim of discrimination under the ADA $?^{91}$

\section{Cleveland v. Policy Management Systems Corp. et al. ${ }^{92}$}

This 1999 case highlights the conflict between different legal definitions of disability and the tension between pursuing gainful employment and receiving public assistance for people with disabilities. In order to quality for protection under the $\mathrm{ADA}$, a person must be able to perform the duties of her job with "accommodation"; but, in order to qualify for SSDI, a person must have a severe disability that prevents her from working. Cleveland tested a person's right to sue under the $\mathrm{ADA}$ while at the same time being eligible for and receiving SSDI. ${ }^{93}$

Cleveland lost her job after having a stroke and applied to receive Social Security Disability Insurance (SSDI) benefits. ${ }^{94}$ She was deemed eligible for the benefits because the stroke left her unable to

${ }^{89}$ Id. at 493.

${ }^{90}$ See, e.g., Thad LeVar, Why an Employer Does Not Have to Answer for Preventing an Eniployee with a Disability from Utilizing Corrective Measures: The Relationship Between Mitigation and Reasonable Accomodation. 16 B.Y.U. J. OF PUB. L. 69 (2001) for further legal analysis of the implications of the Sutton Trilogy.

${ }_{91}$ Cleveland v. Policy Management Systems Corporation et al. 526 U.S. 795 (1999).

92 Id.

${ }^{93} \mathrm{Id}$. at 805

${ }^{94} \mathrm{Id}$. at 798 . 
work. ${ }^{95}$ Before she started receiving the SSDI benefits, she filed suit under Title I of the ADA claiming that her former employer, Policy Management Systems Corp., had failed to make a reasonable workplace accommodation for her. ${ }^{96}$

The lower courts concluded that Cleveland's eligibility for SSDI prevented her from filing suit under the ADA. ${ }^{97}$ The Supreme Court, however, ruled that applying for and receiving SSDI benefits does not automatically prevent the recipient from pursuing an ADA claim. ${ }^{98}$ The Court cautioned that a potential plaintiff still would have to show that, in her particular circumstance, she could have performed her job if appropriate accommodations had been made. ${ }^{99}$ It then remanded the case to the lower court to hear Cleveland's specific argument on this matter. ${ }^{100}$

In Cleveland, the Supreme Court showed an understanding that disabilities can change over time and that reasonable accommodations can permit a person to work who otherwise might not be able to. This decision was also consistent with Congress' intention to facilitate a disabled individual's return to work that it had demonstrated in the same year with the passage of the Work Incentives Improvement Act. As such, the Court's ruling in Cleveland should pave the way for many more people with disabilities to return to work while maintaining the health care and other government benefits that may be necessary to keep them employed.

\section{Board of Trustees of the University of Alabama et al. v. Garrett et al. (Garrett) $^{101}$}

In early 2001, Garrett tested the constitutionality of the ADA's provision allowing disabled state employees to sue a state for money damages. ${ }^{102}$ Patricia Garrett and Milton Ash filed separate suits against their employer, the University of Alabama, in which they sought monetary damages under Title I of the ADA for allegedly failing to

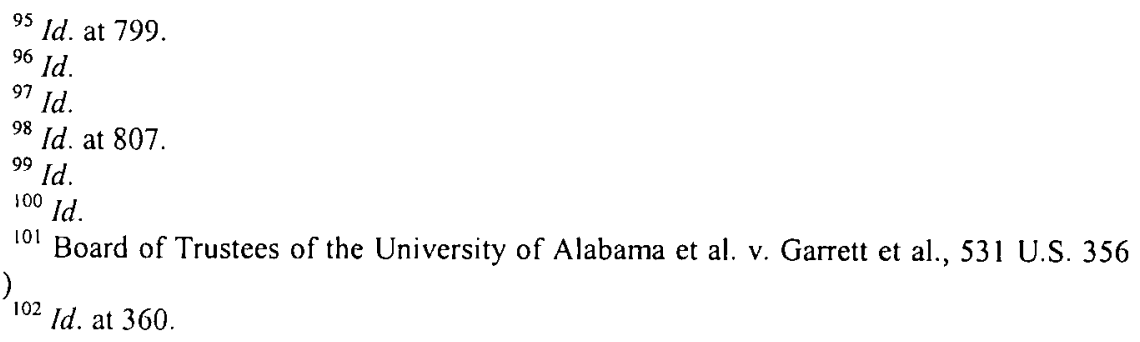


make reasonable accommodations to their work environment. ${ }^{103}$ The Garrett case turned not on the plaintiffs' actual disability or qualifications for accommodation, but on the proper procedure for bringing a case and collecting damages under the ADA. ${ }^{104}$ The State of Alabama argued that suing in federal court to recover monetary damages from the state violated the Eleventh Amendment. ${ }^{105}$

The Supreme Court agreed with Alabama, and held that Congress did not have the authority to subject the states to ADA suits for monetary damages because Congress only has the authority to do so if the state has violated the Fourteenth Amendment. ${ }^{106}$ In order for Garrett to prevail in this case, the Court reasoned, she would have to show that Alabama had exhibited a "pattern of discrimination in its hiring practices against people with disabilities." 107 According to the majority opinion, the facts in the case did not reveal such a pattern, and there was therefore no violation of the due process clause of the Fourteenth Amendment. ${ }^{108}$

After Garrett it will be difficult to sue a state for monetary damages under the ADA. The United States can sue a state for monetary damages due to discrimination and private individuals can sue for injunctive relief. ${ }^{109}$ Private citizens cannot, however, sue states for monetary damages. This poses a dilemma for an entire class of individuals with disabilities who are employed by state agencies and institutions such as public universities. Under Title I, state employers are still required to make reasonable accommodations to people with disabilities, but in cases where they decline to do so, people with disabilities' legal remedies may be limited to injunctive relief. Some

${ }^{103}$ Id. at 362

${ }^{104}$ Id. at 372 .

${ }^{105}$ The relevant part of the Eleventh Amendment states that "The Judicial power of the United States shall not be construed to extend to any suit in law or equity, commenced or prosecuted against one of the United States by Citizens of another State." The text of the 11 th Amendment can be found in the Nat'l Archives at http://www.archives.gov/exhibit_hall/ charters_of_freedom/constitution/amendments_11-27.html (last visited Jan. 10, 2003).

${ }^{10 \overline{6}}$ The relevant text is Section 1 of the $14^{\text {th }}$ Amendment, which is the Due Process clause. The text of the $14^{\text {th }}$ Amendment can be found in the Nat'l Archives, at http://www.archives.gov/exhibit_hall/charters_of_freedom/constitution/amendments_11-

27.html (last visited Jan. 3, 2003).

${ }^{107}$ See Garrett, 531 U.S. 356.

${ }^{108} \mathrm{Id}$.

${ }^{109}$ Injunctive Relief is a court-ordered act or prohibition against an act or condition which has been requested in a petition to the court for an injunction. Such an act is the use of judicial authority to handle a problem and is not a judgment for money. 
commentators believe that other parts of the ADA may also now be at risk of being declared unconstitutional. ${ }^{110}$

\section{Toyota Motor Manufacturing, Kentucky, Inc. V. Williams ${ }^{111}$}

Toyota v. Williams, which was decided in early 2002, is another Supreme Court case that further limited the boundaries for ADA discrimination cases. ${ }^{1 / 2}$ In this case, the Supreme Court defined what it believed to be the proper standard for interpreting the ADA's definition of disability in individual cases. ${ }^{113}$ Ella Williams, an assembly line worker at Toyota, developed bilateral tendonitis and carpal tunnel syndrome as a result of her job. ${ }^{114}$ The company made some accommodations, but then later fired Williams when she could not satisfactorily perform her duties. Williams sued, claiming that Toyota did not provide the reasonable accommodation she believed she was entitled under Title I. ${ }^{115}$

The Supreme Court declared that having a disability that was only work-related is not enough to qualify a person for protection under Title I. ${ }^{116}$ The Court focused on the "major life activity" provision of the ADA's definition of disability, and found that a person who could function normally in other aspects of life, such as housework and childrearing, was not really disabled for the purposes of the ADA. ${ }^{117}$

If this case is taken as precedent, future claims under Title I of the $\mathrm{ADA}$ for workplace compensation must not rely solely on workplace impairment. In fact, showing specific occupational impairment may be less important than showing general impairment of routine daily activities. This poses a new difficulty for ADA Title I claimants who, to have a case at all, must at least show that their disability prevents them from performing the tasks associated with their job. A claimant who attempts to show severe impairment of several life activities may

${ }^{110}$ Some Title II and III provisions could potentially be interpreted as "disproportionate to any unconstitutional conduct that conceivably could be targeted by the Act" because they create broad requirements for states and public entities to make accommodations to people with disabilities. For further discussion of the implications of Garrett, see, e.g., The Bazelon Center for Mental Health Law, The Garrett Case: New Challenge to the ADA, available at http://www.bazelon.org/garrettcase.html (last visited Dec. 12, 2002).

111 Toyota Motor Mfg, Ky., Inc. v. Williams, 534 U.S. 184 (2002).

112 Id.

${ }^{113} / d$. at $193-95$.

${ }^{114}$ Id. at 187.

${ }^{115} \mathrm{Id}$.

${ }^{116} / d$. at $200-03$.

${ }^{117} I d$. at 202. 
run the risk of appearing to be incapable of performing the minimal requirements of her job, making her ineligible for protection under the ADA.

Even if a person can show that he is impaired in a major life activity, employers may still not be required to make accommodations if they can show that a particular accommodation is not "reasonable." This was the issue at stake in another recent Supreme Court case.

\section{U.S Airways, Inc. v. Barnett ${ }^{118}$}

This case, also decided in early 2002, addresses the scope of the reasonable accommodation provision of Title I of the ADA. ${ }^{119}$ Robert Barnett injured his back while working as a cargo handler for U.S. Airways and was transferred to a mailroom job. ${ }^{120}$ When the mailroom position was opened to bidding by senior employees under the company's seniority system, Barnett requested that an accommodation be made under the ADA to allow him to remain in the mailroom job. U.S. Airways refused and fired him. ${ }^{121}$

The Court ruled in favor of U.S. Airways, finding that the accommodation Barnett had requested, making an exception to its seniority rule, was not a reasonable accommodation because it would place undue hardship on the company and its non-disabled employees. ${ }^{122}$ The Court defined the issue of accommodation very narrowly -- in terms of exceptions to companies' seniority systems and not in terms of general disability accommodations -- which suggests once again that it intends to limit the scope of the ADA in employment-

${ }^{118}$ U.S. Airways, Inc. v. Barnett, 122 S. Ct. 1516 (2002).

${ }^{119} \mathrm{Id}$.

${ }^{120} I d$. at 1519 .

${ }^{121} \mathrm{Id}$.

122 The Court's reasoning was actually quite involved, focusing on the issue of the importance of a seniority system in a company's hiring and promotion practices. An excerpt of the opinion illustrates this: "A typical seniority system provides important employee benefits by creating, and fulfilling, employee expectations of fair, uniform treatment-e.g. job security and an opportunity for steady and predictable advancement based on objective standards-that might be undermined if an employer were required to show more than the system's existence." "Any such alteration of that policy would result in undue hardship to both the company and its non-disabled employees." Ordinarily, therefore, the accommodation that Barnett has asked for would be unreasonable. He must, as a result, bear the burden of proof showing special circumstances that make an exception from the seniority system reasonable in this particular case. And to do so, he must explain why, in the particular case, an exception to the employer's seniority rule can constitute a "reasonable accommodation" even though in the ordinary case it cannot. Because the lower court took a different view of the issue, the Supreme Court remanded to the Court of Appeals for further judgment. See Barnett, 122 S. Ct. 1516. 
based claims. $^{123}$ As a precedent, this case creates an uncertain future for Title I claims. Any number of "typical business practices" may be invoked to deny a request for accommodation by an employee with a disability, and businesses may interpret U.S. Airways to signify that they are protected from prosecution if they do so. ${ }^{124}$

\section{Chevron U.S.A. Inc. v Echazabal ${ }^{125}$}

The latest 2002 decision by the Supreme Court regarding an ADA claim takes on an entirely new issue that was not raised by any of the previous cases we have reviewed: whether a company can refuse to hire a person with a disability because the job for which he has applied would put the applicant at risk for physical injury because of the nature of his disability. In other words, can a company discriminate against a person with a disability "for his own good"?

Section II of the ADA Title I contains a provision that defends an employer's ability to make "a requirement that an individual shall not pose a direct threat to the health and safety of other individuals in the workplace." "126 The EEOC implementing regulations take this a step further, allowing that employers may "include a requirement that an individual shall not pose a direct threat to the health and safety of the individual or others in the workplace."127 Mario Echazabal had liver damage due to Hepatitis $C$. $^{128}$ Chevron refused to hire him because of this condition, claiming that exposure to chemicals around its oil refinery might exacerbate his liver condition. ${ }^{129}$ The Supreme Court found that the ADA does not preclude the EEOC rule and that Chevron was justified in not hiring Echazabal for his "own good."130

The Court did not address the question, however, of whether Chevron would be required to make a "reasonable accommodation" that would allow Echazabal to work safely at its oil refinery or elsewhere. $^{131}$ It therefore remains to be seen whether an employer would need to make a job modification, such as relocation to another office or factory, for people whose disability places them in harm in

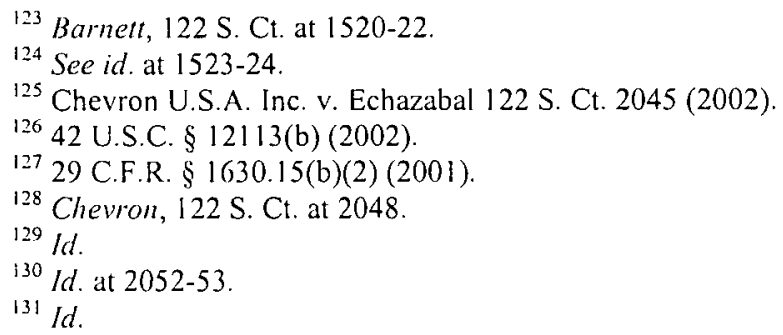


their current or potential work environment. Subsequent cases may address this, but in the near future we can expect more employers to use the "for his own good" defense in employment-related ADA cases.

\section{ADA Title II}

Title II of the ADA addresses a set of quality of life issues for people with disabilities by increasing their access to a variety of activities and services that allow them to participate in society. It applies to public entities including government agencies that provide services to the general public. It prohibits discrimination against people with disabilities in a variety of areas including health care, recreation and social services, among others. In regard to people with disabilities who require facilitated living arrangements, Title II calls for people with disabilities to be placed in the most integrated setting possible that is appropriate for their needs. In this section, we address the one Supreme Court case with broad implications for people with disabilities. In contrast to the Title I employment cases previously discussed, the 1999 Olmstead v. L.C. decision represents a victory for people with disabilities in their quest for equal access to adequate and appropriate public services.

\section{Olmstead v. L.C. ${ }^{132}$}

In Olmstead v. L.C., which was decided in 1999, the Supreme Court dealt with the question of what constitutes an appropriate living arrangement for people with disabilities under the ADA. ${ }^{133}$ In this case, two women who were both mentally retarded and being treated for psychiatric disorders voluntarily entered an institutional or inpatient treatment program. $^{134}$ After a period of treatment, their treatment professionals concluded that they were ready to enter a less restrictive setting: a community-based treatment program. ${ }^{135}$ The state

${ }^{132}$ Olmstead v. L.C. 527 U.S. 581 (1999)

133 The Court first noted the need for such a decision: "Institutional placement of persons who can handle and benefit from community settings perpetuates unwarranted assumptions that persons so isolated are incapable or unworthy of participating in community life and cultural enrichment." It then addressed what constitutes an appropriate arrangement, which includes that "States' treatment professionals have determined that community placement is appropriate [given their medical and physical needs], the transfer from institutional care to a less restrictive setting is not opposed by the affected individuals, and placement can be reasonably accommodated, taking into account the resources available to the state and needs of others with mental disabilities." Id. at 587,600.

${ }^{134} \mathrm{Id}$. at 588.

${ }^{135}$ Id. at 587 . 
of Georgia, however, did not place them in a community-based setting because of a lack of available places and funding. ${ }^{136}$ The Supreme Court found that failing to remove these women from the more restrictive institutional setting violated Title II of the ADA because their treatment professionals had indicated that an integrated community setting was more appropriate for their needs. ${ }^{137}$ The Court's ruling was based on the finding that: “. . . Institutional placement of persons who can handle and benefit from community settings perpetuates unwarranted assumptions that persons so isolated are incapable or unworthy of participating in community life." "138 This decision confirms the Court's approval of the federal policy goal of increasing access to community services and independent living for people with disabilities, which is evident in other Titles of the ADA and the Fair Housing Act.

One ramification of Olmstead is that unjustified confinement of people with disabilities in institutional settings by the state is illegal. That is, community-based programs should be used whenever the individual is capable of benefiting from them and desires them. It also makes clear that a lack of funding cannot be used as the sole justification for not placing people with disabilities in the least restrictive or most integrated setting possible. A later decision by a Pennsylvania district court, however, found that the state could choose to place a person with a disability in a less restrictive setting against the will of the person with the disability. ${ }^{139}$ This creates a potentially troubling precedent for people with disabilities because it often costs states more to house individuals in institutional environments that in community-based living settings.

\section{ADA Title III}

Title III of the ADA prohibits discrimination in access to public accommodations, including those accommodations owned and operated privately but open to the public. In the two major Supreme Court cases that have dealt with Title III, the Court addressed the question of whether a health care provider can treat HIV positive patients differently than his general patient population; and whether the Professional Golf Association must make accommodations for a

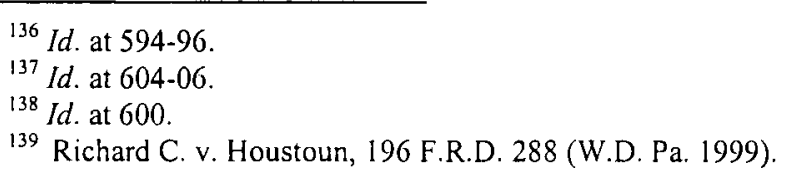


contestant so that he may participate in its annual tournament. Like Olmstead, these two Title III cases, Bragdon v. Abbot et. al. and PGA Tour v. Martin were victories for disability rights.

\section{Bragdon v. Abbott et. al. ${ }^{140}$}

The ADA allows the exception that services do not need to be provided to people with disabilities if doing so would pose a direct threat to others. ${ }^{14}$ Just what constitutes a direct threat to others is sometimes unclear, however, and it was this confusion that this 1998 Supreme Court case addressed. Abbott had HIV that had not manifested its most serious symptoms when she went to a dentist's office where he found a cavity. ${ }^{142}$ The dentist, Bragdon, said that it was his policy to fill the cavities of HIV patients at the hospital and that if Abbott wanted the cavity filled, she would need to pay for the use of the hospital. ${ }^{143}$ Abbott then filed suit under Title III of the ADA, claiming that she was discriminated against because of her HIV status. ${ }^{144}$

Chief among the Court's findings was that an HIV infection constitutes a disability regardless of whether it is yet symptomatic. ${ }^{145}$ While full-blown AIDS had been considered a qualified disability since the passage of the ADA, before Bragdon, the disability status of HIV positive individuals was less clear. The Court also declared that reproduction and child bearing are major life activities for the purposes of an ADA disability claim, a finding that could be important in infertility being declared a disability. ${ }^{146}$ However, the Supreme Court declined to comment on whether the risk to the dentist was sufficient

${ }^{140}$ Bragdon v. Abbott, 524 U.S. 624 (1998)

${ }^{141} 42$ U.S.C. $\S 12182(\mathrm{~b})(3)(2002)$ (provides "Nothing in this title shall require an entity to permit an individual to participate in or benefit from the goods, services, facilities, privileges, advantages and accommodations of such entity where such individual poses a direct threat to the health or safety of others.").

${ }^{142}$ Bragdon, 524 U.S. at 629.

${ }^{143} / d$.

${ }^{144} \mathrm{Id}$.

${ }^{145} I d$. at $641-44$.

146 RESOLVE: The Nat'I Infertility fiss'n since 1974, Supreme Court Rules: Reproduction is a Major Life Activity (1998), available at http://www.cybercom.net/ - resolve/resolve.org/ advabbt.htm (last visited Jan. 13, 2003); Catherine T. Barbieri, Asymptomatic, HIV-Positive Individual Disabled under ADA, Supreme Court Rules, FROF Articles (1998), available at http://www.frof.com/articles/artDetail.asp?id $=120$ (last visited 12/12/02); see also Peter K. Rydel, Redefining the Right to Reproduce: Asserting Infertility as a Disability Under the Americans with Disabilities Act, 63 ALBANY L. REV. 593 (1999), for further discussion of the legal ramifications of Bragdon. 
grounds for the dentist to refuse to fill the cavity at his office. ${ }^{147}$ The case was remanded to the Court of Appeals for consideration of this question. $^{148}$ The Court of Appeals decided that there was no direct threat posed and decided the case in favor of Abbott. ${ }^{149}$

\section{PGA Tour v. Martin ${ }^{150}$}

The PGA Tour case addressed the question of what constitutes a "reasonable accommodation" to people with disabilities under Title III of the ADA. ${ }^{151}$ The Professional Golf Association (PGA) sponsors a three-stage annual qualifying tour and tournament. ${ }^{152}$ During the first two stages of the tournament, golf carts are permitted for everyone. ${ }^{153}$ During the last stage, no one may use a cart. ${ }^{154}$ Martin has a circulatory disorder that prevents him from being able to walk the golf course as required during the third stage of the tournament. ${ }^{155}$ When Martin submitted medical documentation and asked for the accommodation of a golf cart, the PGA denied his request, stating that the fatigue produced by walking the golf course was an important part of the game, and that allowing the cart fundamentally altered the game of golf. ${ }^{156}$ The Supreme Court ruled that the use of a cart qualified as a reasonable accommodation under Title III of the ADA and that Martin's disability fatigued him enough that the use of a cart would not alter the nature of the tournament. ${ }^{157}$

This decision expands the scope of the ADA Title III provision in two ways. First, it officially expands the range of ADA protections to include quality of life issues such as recreation and other social activities. The $\mathrm{ADA}$ language made it clear that these were protected

${ }^{147}$ Bragdon, 524 U.S. 624.

148 Id.

149 This finding was based on, among other evidence, the 1991 American Dental Association Policy on HIV, which indicates: "Current scientific and epidemiologic evidence indicates that there is little risk of transmission of infectious diseases through dental treatment if recommended infection control procedures are routinely followed. Patients with HIV infection may be safely treated in private dental offices when appropriate infection control procedures are employed. Such infection control procedures provide protection both for patients and dental personnel."

${ }^{150}$ PGA Tour, Inc. v. Martin, 532 U.S. 661 (2001).

${ }^{151}$ Id.

$152 \mathrm{Id}$. at 665

${ }^{153} \mathrm{Id}$. at 666 .

${ }^{154} \mathrm{Id}$.

$155 / d$. at 668 .

${ }^{156} \mathrm{Id}$. at 669 .

${ }^{157}$ Id. at $688-91$. 
activities, but before PGA Tour, the issue had not been tested at the Supreme Court level. Second, it extends public entities' responsibility to make accommodations to include altering the nature of the public events they sponsor, including established rules for participation. Previously, Title III was interpreted to apply primarily to issues of physical accessibility such as ramps and lifts. At a time when the Supreme Court seems to be limiting the scope of ADA Title I employment protections, it is significant that the Title II and III cases it has decided in the past four years have expanded protections for people with disabilities in the critical areas of public and private accommodations.

\section{IDEA Cases}

The other major area in which the Supreme Court has been active is education for students with disabilities. Although these cases have not been as high profile as ADA cases, they nonetheless present a number of important implications for disabled people's access to important social services. The Individuals with Disabilities Education Act of 1990 requires that students with disabilities have access to a free and appropriate public education. Just what constitutes an appropriate education, however, has been the major focus of legal issues surrounding this important policy area. Between 1985 and 1998 this issue was elevated to the level of the Supreme Court four times. In two cases (1985 and 1993), the Court declared that a state must pay for educational services for students with disabilities rendered outside the public school system. And in another two cases (1993 and 1998) it decided that a state must pay for extra services (an interpreter and a medically qualified nursing aid) to be available during school hours for a child with a disability. Because these cases naturally fall into these two categories, we present them as such. On the whole, these cases represent successes for students with disabilities in that they have all upheld the IDEA regulations requiring states to provide free and appropriate educational experiences for disabled students.

Florence Co. v. Carter ${ }^{158}$ and Burlington v. Mass. DOE ${ }^{159}$ Whether a state must pay for a student with a disability to be educated in a private setting is an issue that is not explicitly addressed by the

\footnotetext{
${ }^{158}$ Florence County School Dist. Four et al. v. Carter. 510 U.S. 7 (1993)

${ }^{159}$ School Comm'n of Burlington v. Dep't of Ed. of Mass., 471 U.S. 359 (1985)
} 
IDEA. The Supreme Court has twice been called on to interpret the IDEA's provisions as they apply to this potential state responsibility. In Florence Co., the Supreme Court found that the state was required to pay tuition for a private school, which the child was enrolled in while negotiations with the school district about the child's IEP were underway. ${ }^{160}$ In a similar case, Burlington, the Court ruled that parents who disagree with a proposed IEP can unilaterally withdraw their child from public school and place them in a private school at public expense, provided that the expense of private education is reasonable. ${ }^{161}$

These decisions have been hailed by disability rights advocates as just what is needed to ensure that the needs of students with disabilities are met, but they also create a tension between rights of students with disabilities and states' ability to educate all students for which they are responsible. Whether a state must endure unlimited expense to provide special services to students with disabilities is unclear, and the limits of the states' obligation will need to be more clearly delineated in the future.

\section{Zobrest v. Catalina Foothills ${ }^{162}$ and Cedar Rapids v. Garrett ${ }^{163}$}

Although the IDEA is clear about states' responsibility to provide appropriate educational services to students with disabilities, the extent to which states must provide additional services that might help students with disabilities participate in the classroom is less clearly stated in the Act. This ambiguity was addressed twice by the Supreme Court in the 1990's.

Often, for a student with a disability to receive appropriate educational services, the student must have additional medical and personal services available during the school day. These services can be expensive and school districts may not routinely make them available. In Zobrest, the school district refused to provide a sign language interpreter to accompany a deaf child to class who had been placed by his parents in a Roman Catholic high school. ${ }^{164}$ The Supreme Court ruled that because this service would be provided if the child was in a public school and since the interpreter was required

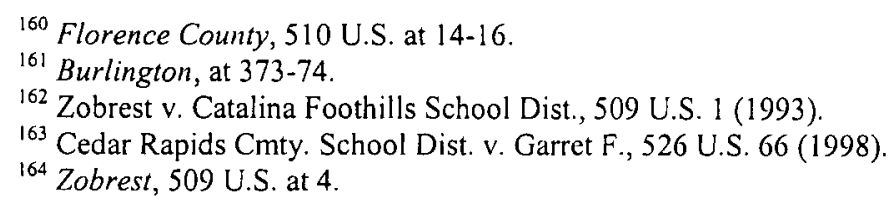


[Vol. 6:1

under IDEA, the school district had to provide the interpreter. ${ }^{165}$ In Cedar Rapids, at issue was a child who needed a full-time medical assistant to attend school. ${ }^{166}$ The Supreme Court said that the school district must pay for the nursing services during school hours and that the cost of this service did not negate the state's responsibility to provide it. ${ }^{167}$

On the whole, these cases uphold the IDEA provisions allowing parents to have substantial input into what constitutes an appropriate education for their child with a disability. Furthermore, as with the ADA Title II and III expansions that the Court has been allowing, these cases represent a significant advancement toward providing truly effective and appropriate educational services for children with disabilities. These services represent a significant cost to school districts; it remains to be seen whether this trend will be maintained as states continue to experience budget tightening in all areas including education and health care.

\section{Continuing Major Issues for People with Disabilities}

Despite the great progress that we have seen in protections and services for people with disabilities since the passage of the ADA in 1990, a set of policy issues that effects all aspects of life for people with disabilities remains to be adequately addressed. For example, employment rates for people with disabilities remain well below the national average, education policy has come into conflict with disability policy in some key areas, access to essential health care services remains problematic for many people with disabilities, and people with disabilities still are not reaping the benefits of technological advances that the rest of society is enjoying. These issues, which are of equal but different importance for individuals with disabilities, have important implications for people with disabilities' overall quality of life. Therefore, we can expect significant attention to be paid by policymakers, the judiciary and people with disabilities themselves to these critical issues in the coming months and years. Several recent initiatives, including President Bush's New Freedom

\footnotetext{
${ }^{165} \mathrm{Id}$. at 12 .

${ }^{166}$ Cedar Rapids, 526 U.S. at 69-70.

${ }^{167}$ Id. at $78-79$
} 
Initiative and the proposed Patients' Bill of Rights, represent the major current efforts that are being made to address these critical areas.

\section{Employment}

Seventy percent of people with disabilities are still unemployed, despite the passage of the Ticket to Work and Work Incentives Improvement Act (TWWIIA) in 1999. As a result, over 6.5 million people receive SSDI benefits, resulting in a total of more than $\$ 80$ billion per year being paid in cash assistance. Efforts are underway to speed the implementation of TWWIIA, which should reduce people with disabilities' reliance on SSDI and other cash assistance programs. However, it will be important to monitor the success of these initiatives in light of recent Supreme Court decisions (i.e., the Sutton Trilogy and Toyota) that appear to be limiting employment protections for some people with disabilities. With the incentives provided under TWWIIA and other tax credit programs for businesses, employers in the future may be less reluctant to hire people with disabilities. In addition, with the financial and health benefit incentives for people with disabilities who work, we may again see employment rates for people with disabilities rise. There are some obvious gaps in TWWIIA -- it does not require states to create Medicaid options for people with disabilities who work -- but it has created a more supportive environment for people with disabilities to seek work and for employers to hire and retain them. Just how successful this legislation will be at increasing employment rates among people with disabilities remains to be seen, and it will surely be the focus of research and policy decision making in the next few years.

\section{Education}

According to statistics published by the U.S. Census Bureau in 2001, people with disabilities of working age (16-64) who achieve a higher level of education are more likely to be working. ${ }^{168}$ However, only $37 \%$ of people with disabilities have more than a high school education

${ }^{168}$ See, e.g., U.S. Census Bureau, Labor Force Status-Work Disability Status of Civilians 16 to 74 years old, by Educational Attainment and Sex: 2001, (2001), available at http://www.census.gov/ hhes/ www/disable/cps/cps201.html (last visited Dec. 12, 2002) (stating that $75.9 \%$ of people with disabilities with no high school diploma are unemployed compared with $64.2 \%$ of those who graduated from high school. For people with disabilities with a bachelor's degree or higher, the unemployment rate is $48.3 \%$ ). 
compared to $82 \%$ of the general population. ${ }^{169}$ The IDEA has been successful at increasing the number of children who receive appropriate educational support, but recent changes in education policy and advancements in treatment and diagnosis of learning disabilities have challenged the scope of its protections for students with disabilities. Three issues in particular loom on the horizon for disability policymakers and educators: zero tolerance, standardized testing policies in schools and evolving eligibility requirements for protection under the IDEA.

\section{IDEA eligibility}

If a student's disability is covered under the IDEA, he is eligible for services such as special education and an Individualized Education Plan (IEP). If the disability is not covered under the IDEA, schools are still required to provide services that will enable the student to participate as fully as possible in the curriculum under Section 504 of the Rehabilitation Act. Accommodations that 504 allows include physical accommodations such as having a note-taker in classes and extra help outside of class for the affected student. 504 does not, however, have the extensive legal framework and requirements of the IDEA. Because of this, which disabilities should be automatically covered under the IDEA and which should be dealt with on an individual basis has become a controversial issue for parents and school districts. There is concern, of course, that expanding eligibility for protection too far will tax schools' available resources and render them unable to provide even basic services to students in need of special services. This tension was heightened by the 1999 revision of the IDEA regulations, which added Attention Deficit Disorder (ADD) and Attention Deficit Hyperactivity Disorder (ADHD) to the list of disorders that are potentially eligible for services under IDEA. ${ }^{170}$ As other disorders are identified as important limitations for student's ability to learn, the IDEA and schools' policies will need to be continually revised to encompass the changing needs of students with disabilities, but these

${ }^{169}$ U.S. Census Bureau, QT-02. Profile of Selected Social Characteristics: 2000 (2000), available at http://factfinder.census.gov/servlet/QTTable?dis_name=D\&geo_id=D\&qr_name $=$ ACS C2SS_EST_G00_QT02\&_lang=en (last visited Dec. 12, 2002).

${ }^{T} 70$ This revision did not allow automatic coverage for ADHD and ADD, and a child with these disorders will still need to show that they have another disability under IDEA in order to qualify for special education services. 
expansions will need to be balanced against the school's financial and logistical constraints.

\section{Zero Tolerance and Students with Disabilities}

Over $75 \%$ of U.S. schools now have zero tolerance ${ }^{171}$ policies regarding drugs, alcohol, weapons, violence and tobacco in school. This new emphasis on zero tolerance in public education has come into conflict with IDEA regulations that state that a student with a disability may not be removed from school for more than ten days in a given school year. After the ten days, schools are required to provide services to help a student achieve his IEP goals and progress with the general curriculum. ${ }^{172}$ Because suspension or expulsion of students with disabilities results in denial of mandated educational services, zero tolerance policies have created both ethical and legal dilemmas for school districts. ${ }^{173}$ While exceptions for weapons and drugs now exist under the IDEA, separate standards or alternative punishments may be required for children with disabilities who run into trouble with schools' zero tolerance policies.

\section{Standardized Tests and Students with Disabilities}

The No Child Left Behind Act of $2001^{174}$ was passed by the 107 th Congress in January 2002. Among other things, this federal law mandates the use of standardized testing in elementary and secondary schools. Several states also have laws that require students to pass an exit exam to graduate from high school. For many students with disabilities, however, these tests are almost impossible to pass if they are taken without accommodations, ${ }^{175}$ and this has led to great concern

171 Zero Tolerance was originally defined as consistently enforced suspension and expulsion policies used in response to weapons, drugs and violent acts in the school setting, but over time these policies have become mandates of harsh, predetermined punishments for a wide variety of rule violations, including general disruptiveness in the classroom.

172 The 1999 revisions to the IDEA included an exception to this rule for drug and weapons offenses. In those cases, removal to an alternative educational setting for a maximum of forty-five days is acceptable. However, the school may still need to provide services to the student if they are necessary for continued progress with the general curriculum and the IEP.

${ }_{173}$ See the Nat'l Mental Health Education Center for suggestions of possible alternatives to Zero Tolerance policies regarding students with disabilities, available at http:// www.naspcenter.org /factsheets/zt_fs.html (Iast visited Jan. 10, 2003).

${ }_{175}^{17}$ Pub. L. No. 107-110.

175 Under the ADA and IDEA regulations, students with disabilities must be given accommodations on standardized tests. These accommodations range from extra time to Braille tests to having the test read aloud to the student. 
among students with disabilities and their advocates that standardized testing rules will have a disproportionate negative effect on disabled students. Indeed, legal action has been taken against testing companies, which often flag tests that are given with accommodations to indicate that the test was taken under non-standard conditions. ${ }^{176}$ Already, students with severe impairments may require alternative assessments, and if this suit is successful, additional accommodations may become available to students with disabilities. The extent to which standardized testing rules will affect a student's IEP has not been determined and we expect to see continued debate about how to appropriately test students with disabilities in a way that accurately assesses their abilities without inappropriately labeling them as disabled.

\section{Housing}

According to the U.S. Census Bureau, only $10 \%$ of people with disabilities are homeowners, compared to almost $70 \%$ of the general population, and people with disabilities who rent their home continue to face problems of access and discrimination. Although Olmstead paved the way for significant progress toward independent living for people with disabilities, it leaves several important questions open in terms of access to appropriate housing facilities: will people with disabilities be forced to live in "community living" facilities even if they prefer not to, and will appropriate supports be made available if they do choose to live in a less restrictive setting? Also, there is the potential for the recent trend in Supreme Court rulings on the scope of the ADA in employment cases to be extrapolated into the area of housing as well. For example, after the Court's ruling in Chevron, will landlords be allowed to refuse rental to people with disabilities who might "risk their own health" by living in an apartment that is, for example, only accessible via an elevator?

\section{Health Care}

Access to appropriate health care services remains an important issue for people with disabilities. Critical health care related legislation is

\footnotetext{
${ }^{176}$ Disability Rights Advocates, a non-profit corporation based in Oakland, filed suit against Educational Testing Service (ETS), the company that makes most of the tests required for students to enter graduate school in the United States, for its practice of flagging tests. ETS settled the suit in February 2001 and agreed to stop flagging graduate level admissions tests that had only the accommodation of extended time. For further analysis of this case, see the ETS website at http://www.ets.org/news/01020701.html (last visited Dec.12, 2002).
} 
being contemplated in Congress that would further enhance protections for people with disabilities, but many of the current proposals are controversial and it is unclear whether any significant progress will be made in the near future. Among the most critical issues that people with disabilities face in health care include the role that managed care plays in providing health care services, the status of mental illness and substance abuse as protected disabilities under the law, and access to prescription drugs.

\section{Insurance and Managed Care}

Insurance coverage for people with disabilities is still a major concern, both for potential beneficiaries themselves, and for their employers and the insurance companies that cover them. Because of their demonstrated high-end use of health care services, ${ }^{177}$ people with disabilities represent a "bad risk" for insurance companies, who are reluctant to cover them. The advent of managed care into the health insurance market has had a disproportionate effect on people with disabilities, and has increased the strain on public disability programs as employers have reduced health care benefits. ${ }^{178}$ In addition to private health insurance plans, many government programs that have traditionally covered people with disabilities, such as Medicare and Medicaid, have begun to be organized under managed care-type arrangements, ${ }^{179}$ sometimes under states' mandates. ${ }^{180}$ The nature of managed care is to limit access to services and sometimes to exclude potential beneficiaries who are known high-end users or who have preexisting conditions. In addition, benefits caps, which set limits for utilization of certain services, such as physical therapy or psychotherapy, are especially problematic for people with disabilities, who have chronic, long term, and usually preexisting health care needs.

${ }^{177}$ See, e.g., Mitch LaPlante et al., Medical Care Use, Health Insurance, and Disability in the United States, Nat'l Institute of Disability and Rehabilitation Research (1995), and Max, W. et al., Medical Expenditures for People with Disabilities, Nat'l Institute of Disability and Rehabilitation Research, (1995), for statistics regarding people with disabilities' higher-thanaverage health care use and expenses.

${ }_{178}$ Nearly 160 million Americans, or roughly $75 \%$ of those who have private health insurance coverage, are now enrolled in managed care health care plans.

${ }_{179}$ Gold, M, et.al., Disabled Medicare beneficiaries in HMOs, 15(5) Health AfFairs 149-62 (Sept-Oct 1997).

${ }^{180}$ Z.C. Hawkinson, and J.E. Frates, JE, Mandated managed care for blind and disabled Medicaid beneficiaries in a county-organized health system: implementation challenges and access issues, 6 AM. J. OF MANAGED CARE 829-36 (July 2000). 
It should be noted, however, that managed care has not been entirely bad for people with disabilities. Many managed care organizations (MCOs) have subcontracted with other insurance companies or service providers to cover the mental health portion of their benefits plans. These mental health carve-outs ${ }^{181}$ seem to be efficient at providing a wide range of mental health care services and have been successful at reducing the cost of mental health benefits. As a result, many employers have become more likely to cover mental health services for their employees. In addition, if used appropriately, the savings created by these cost reductions can be used to provide more services and cover more people who desperately need health care. Controversy in this area revolves around just how these savings are achieved and used, ${ }^{182}$ and we can expect increased scrutiny to be applied to how MCOs use carve-outs in other benefits areas such as prescription drugs and long term care services for people with disabilities.

The changing health care industry has also raised questions about the role of the ADA in the health insurance market, such as whether insurance companies, including managed care organizations, can be held liable for ADA violations ${ }^{183}$ and the rights of patients with disabilities who are enrolled in managed care plans. ${ }^{184}$ Specifically, eligibility criteria, outcome distinctions and the accessibility of treatment facilities for people with disabilities may need to be treated differently by MCOs. ${ }^{185}$ In addition, concern has been raised over

181 See, e.g., Goldman, W. et al., More evidence for the insurability of managed behavioral health care, 18(5) HEALTH AfFAIRs 172-81 (1999); C.A. Ma and T. McGuire, Costs and Incentives in a Behavioral health Carve-out, 17(2) HEALTH AFFAIRS 53-69 (1998), for a discussion of mental health 'carve-outs' and their success at achieving cost savings while maintaining high-quality care.

182 Whether the savings generated from managed care is due to increased efficiency and the elimination of inappropriate care instead of the denial of essential services is a question that has bcen highlighted by countless tragic anecdotes of people being harmed as a result of MCOs' coverage determinations.

183 See, e.g., J.S. Manning, Are insurance companies liable under the Americans with Disabilities Act? 88 CAL. L. REV. 607-5I (2000); L. McClain, Shopping center wheelchair accessibility: Ongoing advocacy to implement the Americans with Disabilities Act, 17(3) PUB. Health Nursing 178-86 (May-June 2000); Nat'l Council on Disability, Position paper on Patients ' Bill of Rights Legislation, Mar. 30, 2001 available at http:/www.ncd.gov/newsroom/ publications/patientshillofrights.html (last visited Jan. 10, 2003).

184 P. B. Herbert and K. A.Young, The Americans with Disabilities Act and Deinstitutionalization of the Chronically Mentally /ll, 27 J. AM. ACAD. PSYCHIATRY L. 603-13 (1999).

185 See, e.g., Gwen Thayer Handelman, Implementing the ADA: Health Benefits Plans and the $A D A$, ILR Program on Employment and Disability, Cornell University (2000), 
whether managed care companies will reduce or restrict the use of independent living facilities for people with disabilities, and whether this will have a negative impact on the health and emotional well-being of people with disabilities who use them. ${ }^{186}$

\section{Mental Health and Insurance}

Almost 15 million Americans with mental illness continue to experience significant inadequacies in access to health care services, due largely to a lack of knowledge about the causes and treatment of mental illness, inadequate insurance coverage and the stigma that remains around the concept of mental illness. ${ }^{187}$ Despite recent advances in treatment for mental illness, ${ }^{188}$ managed care companies and employers often deny these services to beneficiaries or severely limit access to them by creating limitations on the number of visits allowed or requiring individuals to pay for part or all of the mental health visit. ${ }^{189}$

available at http://www.jan/wvu.edu/links/adalinks.htm (last visited Dec. 12, 2002), for a discussion of the ways in which MCOs may be required to treat people with disabilities differently than their typical enrollees, including legal restrictions prohibiting benefit limitations on treatment of diseases such as HIV/AIDS and certain mental illnesses.

${ }^{186}$ Over the last two decades there has been a significant trend toward increasing independent living arrangement for people with disabilities, which allows them more freedom and control of their lives. This trend is likely to be enhanced as a result of the Olmstead decision, but whether this decision applies to MCOs remains controversial. See, e.g., Andrew Batavia, Independent living centers, medical rehabilitation centers, and managed care for people with disabilities. 80(10) ARCH. PHYS. MED. REHABIL. $1357-60$ (Oct. 1999), for a discussion of independent living centers and managed care.

187 See, e.g., David Mechanic, Removing Barriers to Care Among Persons with Psychiatric Symptoms. 21(3) HEALTH AfFairs 137-147 (2002).

${ }^{188}$ Norquist, Grayson and Steven E. Hyman, Advances in Understanding and Treating Mental Illness: Implications for Policy, 18(5) HEALTH AFFAIRS 32-47 (1999).

${ }_{189}$ This may change if the Mental Health Equitable Treatment Act of 2002 (MHETA), currently under debate in Congress, becomes law. This legislation is proposed to replace the Mental Health Parity Act of 1996, which expired at the end of 2001. The major stumbling block for the MHETA, as was true in the debate over the MHPA of 1996, has been the projected cost of the legislation in terms of potential increases in individual premiums for mental health, or overall cost for health insurance plans. Actual evidence, however, does not confirm this fear, and it seems more likely that the cost argument reflects a general lack of political support for mental health legislation. See, e.g., R.G. Frank, et.al., The Politics and Economics of Mental Health 'Parity' Law's, 16(4) HeAlTH AfFAIRS 108-19 (1997), and M. Sing, et. al., The Costs and Effects of Parity for Mental Health and Substance Abuse Insurance Benefits (1998). DHHS, SAMHSA; Rockville, MD, for empirical analyses of the costs of the original mental health parity legislation. 


\section{Substance Abuse}

Substance abuse has been a more controversial issue in disability policy than have other forms of mental illness. According to a 2001 Robert Wood Johnson Foundation report, ${ }^{190}$ substance abuse is the nation's number one health problem, costing the country over $\$ 400$ billion annually. According to the report, more than 18 million people who use alcohol and 5 million who use illicit drugs currently need treatment, but fewer than one quarter of these actually receive treatment. Legal protections for people with substance abuse problems are also lacking. For example, although substance abuse is a recognized disability under the $\mathrm{ADA},{ }^{191}$ its Title I provisions do not cover people who are drug or alcohol abusers if their drug use directly contributed to their employer's decision to terminate them. ${ }^{192}$ Even so, many states have recognized the importance of substance abuse as a medically treatable condition, ${ }^{193}$ and have passed laws requiring insurance coverage for substance abuse treatment. As of September 2001, twenty-one states had laws relating to substance abuse. ${ }^{194}$ The power of these state provisions, however, remains questionable in light of the fact that the proposed federal Mental Health Equitable Treatment Act ${ }^{195}$ would not require health plans to offer substance abuse services.

\section{Prescription Drugs}

People with disabilities can often function quite well with the help of prescription drugs, but many lack adequate insurance coverage to pay for their prescriptions. When people with disabilities cannot get their

${ }^{190}$ Robert Wood Johnson Foundation, Substance Abuse: The Nation's Number One Health Problem (2001), available at http://www.rwjf.org/publications/other.jsp\#295 (last visited Dec. 12, 2003).

'191 Under the ADA, substance 'abuse' and 'dependence', but not substance 'use', are recognized disabilities.

${ }^{192}$ This exclusion was designed to protect employers from having to employ individuals whose substance abuse interferes with their own or others' ability to perform in the workplace. The exclusion, however, does not apply to persons who "have successfully completed" a supervised drug rehabilitation program and are "no longer engaging in the illegal use of drugs" in order to protect employees who might be discriminated against because of past illegal use of drugs.

${ }^{193}$ State legislatures based this determination on the DSM-IV and the ICD-9, which both recognize substance abuse as treatable disorders.

${ }^{194}$ Some states have two or more substance abuse laws relating to different types of insurance plans. For example, South Carolina requires group plans to offer SA benefits and state employee plans to have full parity for SA benefits.

195 As of August, 2002, this proposed bill has passed the Senate as S. 543, and is currently being debated by the House as H.R. 4066 . 
prescription filled due to lack of money, their conditions can be exacerbated and they may incur added medical expenses to compensate. ${ }^{196}$ Proposals to expand Medicare to include coverage for prescription drugs for the most part ignore the roughly 17.5 million people with disabilities under age 65 who need prescription drugs. ${ }^{197}$ For these individuals, finding a way to pay for their prescriptions will become increasingly difficult as insurance premiums rise in step with drug prices. Several states have implemented trial programs to help people with disabilities pay for their prescriptions, and some of these have been quite successful. ${ }^{198}$ Unfortunately, with recent cuts to states' budgets these may be among the first programs to be eliminated. In order to fill the gap created by differences in coverage between Medicare proposals and state programs, policymakers may need to focus on providing prescription drug coverage for all people with disabilities who do not have access to them otherwise.

\section{Patients' Bill of Rights}

Several versions of a Patients' Bill of Rights (PBOR) are currently under consideration in Congress. Any one of these bills, if passed, would create or enhance legal protections for people with disabilities. According to the National Council on Disability (NCD), because people with disabilities are high-end users of health care services, they:

"are a litmus test for assessing the effectiveness of PBOR legislation. In other words, if a PBOR protects people with disabilities, it is bound to adequately protect the rights of all healthcare consumers." ${ }^{\text {,199 }}$

In its March 2001 position paper on PBOR legislation, the NCD recommended a series of provisions that a PBOR should include in order to be maximally effective in protecting the health care rights of

196 See, e.g., Disturbing Truths and Dangerous Trends: The Facts About Medicare Beneficiaries and Prescription Drug Coverage, Nat'l Econ. Council (1999); see also supra note 33.

197 See supra note 32.

198 For example, Illinois has created the "Circuit Breaker and Pharmaceutical Assistance" program to help pay for prescription drugs for low income elderly and disabled citizens. Other states with similar programs include: Connecticut, Delaware, Maryland, Michigan, Missouri, New Jersey, New York, Pennsylvania, Rhode Island, Maine and Vermont. For more on state pharmaceutical assistance programs see http://www.cancercareinc.org/ services/state_programs.htm.

${ }^{199}$ See Nat'l Council on Disability, supra note 183. 
people with disabilities. Included among those recommendations was the imperative that any potential bill cover all 161 million Americans who have private insurance coverage. ${ }^{200}$ Specific additional provisions might include: 1) mandated direct access to specialty care and standing referrals to a specialist, 2) continuity of care for people with disabilities by allowing continued access to a provider even if a plan's network is changed, 3) access to clinical trials for new therapies and medications and 4) strong privacy regulations that prevent plans from using the results of genetic or diagnostic tests or other information to deny coverage. While a Patient Bill of Rights alone would not solve all the health care access problems that people with disabilities face, passing such a law would serve to fill some of the critical gaps that people with disabilities now face.

\section{Caring for the Caregivers}

Families are often affected as much by disability as people with disabilities themselves. The elderly disabled especially rely on family caregivers as a major source of care, and this family burden creates important social, emotional, financial, psychological and occupational problems for family members. ${ }^{201}$ These problems become increasingly important as independent living and community care are being advocated and more care is being provided in the home or community. As this trend continues, it will be important to assess the impact on family caregivers of changes in the location and financing of long term care for people with disabilities, and changes in public policy will be required to address the needs of entire families, not just individuals with disabilities, as they negotiate caring for a disabled family member.

\section{Technology}

There are several important legal and social issues surrounding technological advances for people with disabilities. In some cases, access to technology is an important quality of life issue for people with disabilities. In other cases, however, technologies such as the

${ }^{200}$ Because roughly $50 \%$ of people with disabilities have private insurance coverage, such a provision would be a minimal first step in protecting the rights of all people with disabilities to receive adequate health care benefits.

${ }^{201}$ Katherine E. Heck, et.al., Parental Employment and Health Insurance Coverage Aniong School-Aged Children with Special Health Care needs, 90(12) AM. J. OF PUB. HEALTH 1856-60 (2000); Ute Thyen, et.al., Employment, Child Care, and Mental Health of mothers caring for children assisted by technology, 103(6) PEDIATRICs 1235-42 (1999). 
Internet are important tools to function in the workplace. Cochlear implants, air travel, film captioning and access to computers and the Internet are some issues that are most critical for people with disabilities at the moment. For the most part, controversy in these areas revolves around how to make assistive technologies more readily available to people with disabilities. However, in some cases, such as with cochlear implants, whether certain technologies should be available at all has also been a source of controversy.

Over 20,000 people have received cochlear implants since their approval by the FDA sixteen years ago. ${ }^{202}$ With the technology available today, about $10 \%$ of the people who receive cochlear implants will be able to communicate without lip reading; most of the remaining $90 \%$ can communicate with the hearing world when the device is combined with lip reading. ${ }^{203}$ For children who are too young to have input in the decision, however, the use of cochlear implants is controversial. ${ }^{204}$ For those who can benefit from and are willing to use cochlear implants, public policy should focus on finding efficient ways to provide this service for people with hearing impairments.

Access to air travel for people with disabilities is problematic for several reasons. This includes the fact that cancellation and delay announcements are often only read over a loud speaker, airports and airplanes are often inaccessible to people in wheelchairs, lack of inflight captioning for safety videos or movies, unfamiliarity of airline staff with the needs of people with disabilities, and, for those with cochlear implants and other assistive devices, the fact that they trigger airport metal detectors. ${ }^{205}$

Closed caption television and films have been hailed as a tool for teaching, reading and learning English, but for the deaf and hard of hearing community, closed captioning is essential. Although the

202 Paul Bacon, Cochlear Implants: Bridging the Sound Gap, Sound and Fury: Cochlear Implants, available at http://www.pbs.org/wnct/soundandfury/cochlear/cssay.html (last visited Jan. 10, 2003).

203 Ronald A Hoffman, Cochlear Implants in Adults and Children, The Harvard Mahoney Neuroscience Institute Letter (1993), available at http://www.doc4ears.com/ cochlear_implants_in_adults_and_.htm (last visited Jan. 10, 2003).

${ }_{204}$ See, e.g., supra nn. 202-03; see also Paul Bacon and Omer Zek, Cochlear ImplantsOpinions, available at http://www.zak.co.il/dcaf-info/old/ci-opinions.html (last visited Jan. 10, 2003), and Nat'l Ass'n. for the Deaf Cochlear Implants and Education: Some Thoughts and Issues (2001) available at http://www.nad.org/infocenter/infotogo/dcc/Cljan01/ Clandeducation. html (last visited Jan. 10, 2003).

205 The Air Travel Wish List, available at http://www.amrad.org/pipermail/tacos/ 1999/001261.html. 
Federal Communication Commission (FCC) requires that $50 \%$ of television be captioned by January 1, 2002, and that television be fully captioned by 2006 , many programs, including news and educational programs, are still not captioned. ${ }^{206}$

The Internet could potentially be an important tool to help people with disabilities work, shop and socialize without having to leave their home, but computer ownership and Internet use among people with disabilities is well below the national average. ${ }^{207}$ For people with disabilities, computers represent more than just a quality of life issue, like they do for so many Americans; they are an opportunity to join the workforce. Given the fact that computers are relatively inexpensive in comparison to physical modifications to workplaces, employers might reasonably provide a home computer as a workplace accommodation to people with disabilities who could then work at home to fulfill their job responsibilities.

\section{New Freedom Initiative}

The Bush Administration has committed itself to advancing protection and support for people with disabilities who strive to be active, productive members of society. In February, 2001, President Bush unveiled the New Freedom Initiative to eliminate barriers to full participation in society for people with disabilities. The New Freedom Initiative $^{208}$ sets out goals for progress, and specifically enables the rapid implementation of a variety of other disability legislation designed to enhance the lives of people with disabilities. For example, the Initiative calls for swift implementation of the Olmstead decision arid the TWWIIA, it calls on other government agencies to develop plans for compliance with workplace accommodations rules, it provides support to businesses attempting to comply with ADA regulations by providing tax credits for expenses incurred for ADA related modifications, and it creates a New Freedom Commission on Mental Health to advise the President on issues related to improving access to treatment and services for people with mental illness. ${ }^{209}$

206 Federal Communications Comm'n, Closed Captioning, available at http://www.fcc.gov/cgb/consumerfacts/closedcaption.html.

207 Stephen Kaye, Computer and Internet Use Among People with Disabilities. U.S. Dep't of Education, Disability Statistics Report 13 (2000).

${ }^{208}$ For more on the New Freedom Initiative, see the White House web page at http://www.whitehouse.gov/news/freedominitiative/freedominitiative.html (last visited Jan. 10, 2003).

${ }^{209}$ For a more detailed description of the New Freedom Comm'n on Mental Health, see 
By targeting several different issues in one initiative, the New Freedom Initiative hopes to create a broad base of support for people with disabilities in multiple aspects of their lives. It does this by balancing the needs of people with disabilities with the legitimate concerns of businesses. At a minimum, this initiative should help to ensure that legislation that is already in place is properly enforced so that people with disabilities can begin to enjoy the benefits and responsibilities of active participation in society.

\section{Conclusions}

Since the enactment of the Rehabilitation Act of 1973, the federal government has been active in the development of legislative-statutory responses to the needs and problems of people with disabilities. Since 1990, with the passage of the ADA, government has been trying to design effective and efficient strategies to deal with several critical dimensions of disability policy: 1) the legal definition of what constitutes a disability, 2) protection against bias and discrimination for people with disabilities, 3) providing meaningful opportunities and incentives for disabled individuals to work, 4) balancing the need for employers to "accommodate" people with disabilities in the workplace with "protecting" employers against unreasonable economic hardship which might be involved in providing such accommodation and 5) balancing the rights and needs of individuals with different types of disabilities (i.e., physical, emotional and learning disabilities) for services and programs provided by government and private entities.

It is worth noting that there has been some tension within government over what the appropriate "governmental" response should be to the problems and needs of people with disabilities. For the past twenty years, the legislative branch has emphasized the need to recognize the special needs of disabled people and to provide appropriate services and protections for them. The judicial response has, however, been somewhat different, especially over the past five years. In all of its recent rulings, the Supreme Court has decided in favor of defendants, finding that Congress did not intend to provide such broad protection under the $\mathrm{ADA}$, and that it did not intend to place

http://whitehouse.gov/news/releases/2002/04/print/20020429.-2.html (last visited Jan. 10, 2003). 
such burden on businesses to make accommodations for people with disabilities.

There are two reasons we believe that there is tension between the Supreme Court and Congress in the development of public policy related to disability. First, there are more than a dozen disability rights laws that prohibit discrimination in a variety of areas of life for people with disabilities. Some of them, in fact, overlap, providing further evidence that Congress is serious about protecting people with disabilities in their attempts to find gainful employment. ${ }^{210}$ As the Supreme Court is fond of reminding us, Congress does not pass laws frivolously, and if its record in this area is any indication, it has not been frivolous in its repeated attempts to provide protection for people with disabilities. The second reason that recent Supreme Court decisions are confusing is their implication that Congress did not intend to place undue burden on employers to accommodate people with disabilities. It is true that Congress wanted to protect businesses from undue hardship and financial burden in ADA related accommodations, but not by exempting them from compliance with the ADA and other laws. On the contrary, Congress has passed several laws that provide tax credits to businesses that make appropriate accommodations to employees with disabilities. ${ }^{211}$ Again, Congress's willingness to support businesses in complying with the ADA is a clear indication that Congress expects businesses to comply. The Supreme Court rulings have had the opposite effect, suggesting to businesses that they will be exempt from ADA regulations. This makes businesses less likely, not more likely, to accommodate people with disabilities in the workplace and in other areas of life.

Legal and public policy for people with disabilities is definitely evolving. It is clear that government has yet to make up its mind as to what the appropriate, effective and efficient response should be to the legal and service needs of disabled individuals. We can expect the courts to continue to address key issues related to protection of

210 The Rehabilitation Act of 1973 and Title I of the ADA both deal with issues of employment-based discrimination against people with disabilities, explicitly prohibiting workplace discrimination in both public and private employment.

211 The Disabled Access Tax Credit, 26 I.R.C. $\$ 44$, The Tax Deduction to Remove Architectural and Transportation Barriers... See 26 I.R.C. $\$ 190$ ), and the Targeted Jobs Tax Credit, 26 I.R.C. $\S 5$ l, replaced by the Work Opportunity Tax Credit (WOTC) Program-- all provide disability-related tax incentives to businesses who are attempting to comply with ADA accommodations requirements. See EEOC facts about Disability-Related Tax Provisions at http://www.eeoc.gov/facts/fs-disab.html (last visited Jan. 10, 2003). 
employees and employers. We also expect further refinement of the definition of disability and differentiation in rights and services for people with different types of disabilities. In addition, there will be a continuing need to balance issues of protection and rights of people with disabilities with the economic interests and rights of employers. Disability policy will be an active and evolving area over the next decade.

Finally, government programs and services are taxed by increasing numbers of people with disabilities (about $\$ 175$ billion per year in direct costs), and this trend is likely to increase. Americans will find that balancing the needs of people with disabilities with other economic and political interests is a challenge that will continue to cause tension as we move forward. New and innovative governmental strategies will be required to deal with this critical legal and policy issue. 
